Portland State University

PDXScholar

\title{
Totiusque ecclesiae suae sanctae; a comparison of the ecclesiologies of St. Augustine and Hans Kung
}

\author{
Edward J. Sullivan \\ Portland State University
}

Follow this and additional works at: https://pdxscholar.library.pdx.edu/open_access_etds

Part of the Christianity Commons, History of Christianity Commons, and the Religious Thought, Theology and Philosophy of Religion Commons

Let us know how access to this document benefits you.

\section{Recommended Citation}

Sullivan, Edward J., "Totiusque ecclesiae suae sanctae; a comparison of the ecclesiologies of St. Augustine and Hans Kung" (1971). Dissertations and Theses. Paper 1464.

https://doi.org/10.15760/etd.1463

This Thesis is brought to you for free and open access. It has been accepted for inclusion in Dissertations and Theses by an authorized administrator of PDXScholar. Please contact us if we can make this document more accessible: pdxscholar@pdx.edu. 
AN ABSTRACT OF THE THESIS OF Edward J. Sullivan for the Master of Arts in History presented December 3, 1971.

Title: Totiusque Ecclesiae Suae Sanctae -- A Comparison of the Ecclesiologies of St. Augustine and Hans Kung.

APPROVED BY MEMBERS OF THE THESIS COMMITTEE:
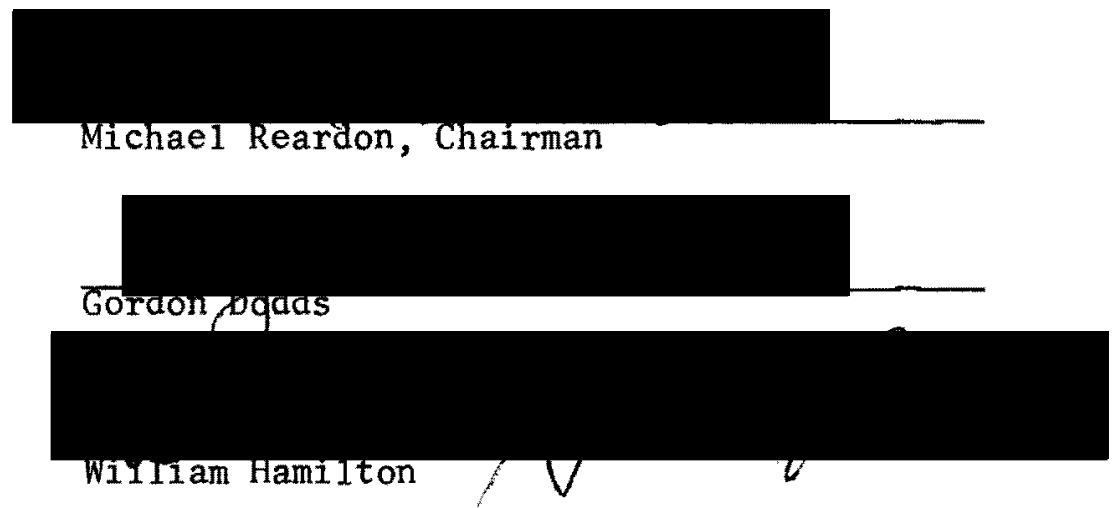

This paper attempts to compare the ecclesiologies of the fourth century Bishop of Hippo and the controversial twentieth century theologian. In doing so, a study is made of each writer independently in order to extract his conceptual models of the Church. Special significance is given to the names each attributed to the Church and the consequences of these names as they pass from an analogical to an ecclesiological sphere. A study is also made of the functions of office within the Church with respect to the fulfillment of specific ministries. Here the two divide, Augustine meets the Donatist challenge by condemning disunity, while urging contemporary Christians to true internal reform, reminding them of the necessity of grace available only through the Church to heal their natures. Special attention is given to two specific topics from Augustine: the use of force to compel 
at least outward conformity, and the belief in the inability of man to do any good outside the Body of Christ.

Kung diverges in another way in different times. He emphasizes the communal nature of the Church as those called by God and, on earth, represented by the ministry of ecclesiological office, including Ecumenical Councils and the Papacy. The Church, according to Kung, is the Kingdom of God moving towards manifestation and must reflect its apocalyptic nature by its witness and proclamation of the Word. He finds fault with the teaching office of the Church for its adherence to verbal propositions and concludes advocating a non-propositional attachment to kerygma.

The contrast between the writers is sharply emphasized by a comparison of their positions on certain points, including authority, the Papacy and finally the four marks or distinguishing characteristics of the Church. The attitudes towards the first two differ markedly on some points, but a consistency of approach towards the four marks of the Church, with the exception of the Apostolic characteristic, can be seen.

Several conclusions are propounded but the essence of each lies in the attitude of each writer towards human nature. Augustine finds the same wholly depraved without grace, which is given through the Word and human collaboration. Kung finds a response to divine call sufficient and is less concerned with limits on freedom in the name of love of neighbor. The interplay between these two schools of thought has punctuated Church history in the same manner as it does human history. 
TOTIUSQUE ECCLESIAE SUAE SANCTAE -- A COMPARISON OF THE ECCLESIOLOGIES OF ST. AUGUSTINE AND HANS KUNG

by

EDWARD J. SULLIVAN

A thesis submitted in partial fulfillment of the requirements for the degree of

MASTER OF ARTS

in

HISTORY

Portland State University

1971 
TO THE OFFICE OF GRADUATE STUDIES:

The members of the Committee approve the thesis of Edward J. Sul1ivan presented December 3, 1971.
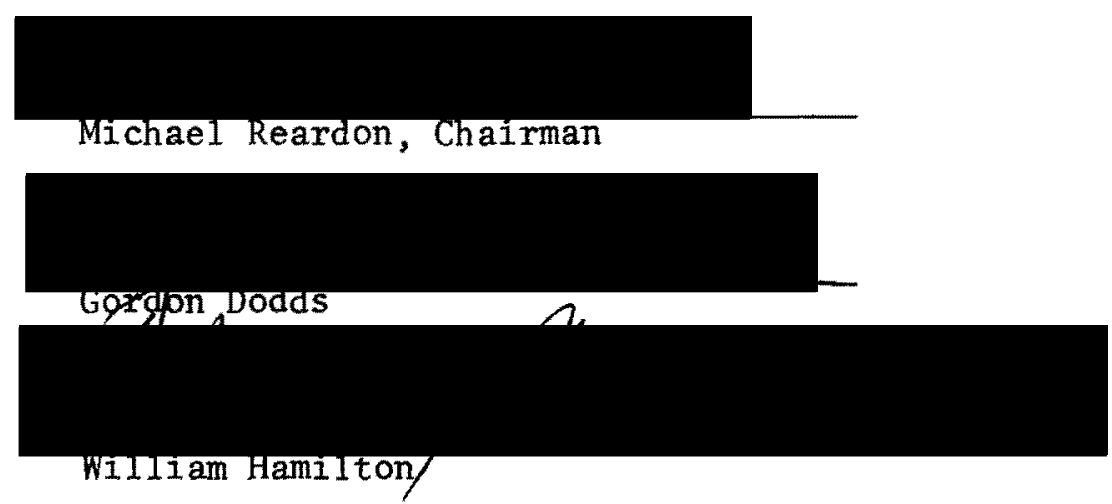

\section{APPROVED :}

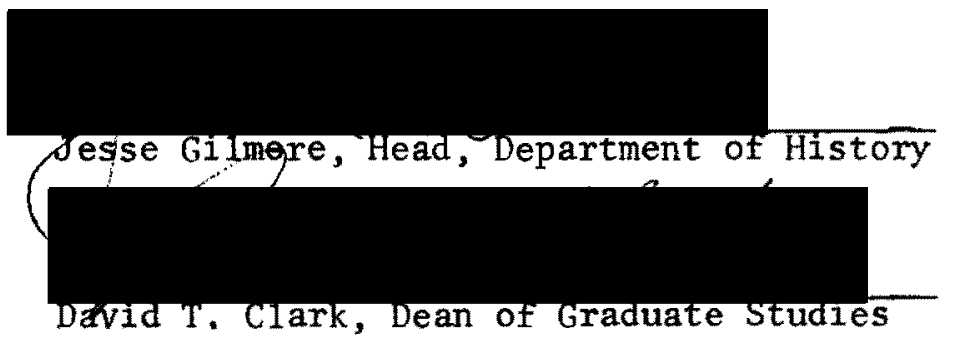

December 3, 1971 


\section{ACKNOWLEDGMENTS}

To Richard Clark for having nurtured in me a love for Augustine and to Michael Reardon for fostering that love. 
TABLE OF CONTENTS

PAGE

ACKNOWLEDGMENTS . . . . . . . . . . . . . . . . . .

INTRODUCTION . . . . . . . . . . . . . . . .

CHAPTER

I AUGUSTINE . . . . . . . . . . . . . . . 5

A. Introduction to Augustine . . . . . . 5

B. The Names of the Church . . . . . . 7

C. The Church and Her Members . . . . . . . 14

D. The Effects of Church Membership . . . . . 20

E. Summary . . . . . . . . . . . . . 24

II HANS KUNG . . . . . . . . . . . . . . . 33

A. Introduction ............. . . 33

B. The Names of the Church . . . . . . . 36

C. Ministry and Charism . . . . . . . . . 39

D. Representation within the Church . . . . . 42

E. The Nature of the Church . . . . . . . . 43

F. The Teaching of the Word . . . . . . . . 45

III A COMPARISON OF SELECTED SUBJECTS . . . . . . . . 57

A. Authority .............. . 57

B. The Papacy . . . . . . . . . . . . 59

C. The Marks of the Church . . . . . . . . 63

1. The Church is One .......... 63 
v

2. The Church is Holy ........ . . 66

3. The Church is Catholic........ . 68

4. The Church is Apostolic ...... 70

CONCLUSION ............................. 78

SELECTED BIBLIOGRAPHY . . . . . . . . . . . . . . 84 


\section{INTRODUCTION}

Relying upon the public life of Jesus, the Acts of the Apostles, the Epistles, and the history of the early Church as authoritative exemplars, Christianity has always impressed upon its adherents the necessity to fulfill their religious duties within a social context, Gnostic and Quietistic trends within the Clurch have been countered by scriptural authority requiring men to involve themselves, in the name of God, in loving and aiding their fellows and in spreading the Gospe]. The fulfillment of these works presupposes a certain institutional. framework.

Further, in order to continue the mystery of the Redemption, Christianity requires some communal form, based on a community of interest, by which men can know of and share in their calling as Christians and continue necessary personal reform, a reform possible only through grace. The allusions made by Christ to His followers as sheep and the Pauline references to the Church as the Body of Christ strengthen this conclusion. In addition, it is membership in this Body, this corporate form, according to scripture, which gives the life of grace necessary to the Christian. (See, for example, I Cor. 10:3,4; I Cor. 15:45; Eph. 4:4, 16.) After belief in Christ and the Word of God, it is then necessary for the Christian to translate that belief with the aid of grace and in a social context, to effectuate his salvation. Following the old Testanent, the fjrst Christians declared themselves to be the people of God in a liew Covenant, 
which had superceded the 01d. Assuming a communal form, they began to manifest signs by which they could be recognized: the "fish" symbol, the common meal, ministers, and so forth. But the primary reason for separation was not mere cultic nuance, but the belief that this corporate people possessed the ability, through grace, to remain faithful to their Covenant-Partner and thereby share in His promised life. The Covenant-People received and dispensed to its members the grace necessary to receive the promises of Christ and also to participate in the presence of the Holy Spirit indwelling within that People, impelling them towards a continuing love of God and man.

The Epistles of Paul elaborate to a greater extent than any other New Testament writer on the nature and work of the Christian community. His stress on the necessity to follow Christ and His immediate followers in demonstrating their union of peace and love, their faithfulness to the teaching of Christ, their desire to spread these teachings to al1 men and the transmission of grace to all men through an ordered ministry are al1 qualities by which Paul distinguished the Covenant-People from all other gatherings and by which he found in them a common consciousness of their uniqueness. These four requisites became the distinguishing features or marks of the Covenant-People.

This Covenant-People, referring to itself as the "Church" (from the Greek "ekklesia," those called forth), saw itself as the vessel through which grace would be transmitted to individual members by the Holy Spirit. The needs and sharings of the Covenant-People were emphasized over those of individuals; indeed, the manifest requirement that members love and aid their fellows out of a love for God rather than selforientation, has always been a fundamental part of Christian eschatology. 
Apostolic and Patristic views of the Church arose out of these basic considerations without the formulation of a detailed ecclesiology, but differences of opinion as to the fulfillment of Christian obligations have required a continually more precise refinement as to the institum tional nature of the Covenant-People.

A comparison of the two writers under consideration serves as an example. Augustinian ecclesiology centers on certain very basic aspects of the Church such as the nature and efficacy of the sacraments, the personal requirements for membership and ministry, without any particular writing addressing itself to the nature of the Church. However, there are assumptions and formulations concerning the Church which may be taken from various works and pieced together to form a theoretical framework. Augustine relies, in the main, upon Scripture and the earlier Christian writers in addition to his own experience. On the other hand, Dr. Hans Kung makes use of the accumulated experience of the Church and of prior treatises touching upon its nature in addition to Scripture. A contemporary scholar, Kung has chosen to address himself to ecclesiology in a systematic manner. As with Augustine, Kung relies on Scripture and tradition but also possesses vastly superior critical tools in pursuing his study. Both writers are Christocentric in emphasis and find this Christocentricity to be distinctive characteristics of their respective ecclesiologies.

This paper will consider each writer independently and do so from his own works, rather than from secondary sources. The use of primary sources frees one from commonly-held prejudices and allows greater latitude for speculation but increases the danger that subtle points may be 
missed. Yet a fresh look at each writer purely from the standpoint of his ecclesiology may uncover, or touch upon without competition from other considerations, a new aspect of his world-view. After independent consideration of the writers in the first two chapters, a comparison of the two, with respect to certain specific common areas with which each was concerned, will be undertaken, along with a consideration of the views of each toward the characteristics or marks of the Church. Finally, some conclusions will be proposed and discussed with regard to the similarities and dissimilarities of the vision held by each as to the place of the Church in the economy of salvation. No synthesis of views is attempted; yet each writer raises, and attempts to answer, some troublesome problems which have beset the Christian through the centuries, arising out of the divinity of the mission of the Church and the humanity of her presence. The resolution of these questions is a matter for theologians; the interest of historians is the response of two Christian writers in wholly different circumstances to the peculiar needs of the church as they saw them. It is to this task that this paper seeks to address itself. 
CHAPTER I: AUGUSTINE

\section{A. Introduction to Augustine}

Augustine of Ilippo was born in Thagaste less than fifty years after the official Edict of Toleration was promulgated by the Emperor Constantine. He died twenty years after Alaric sacked Rome at a time when the Empire was divided and the western portion was falling to the steady blows of the barbarian tribes all around her borders. His life was no less eventful than that of the Empire. The times transformed him no less than they did the state.

It is impossible to summarize all of the events and contemporaries who influenced Augustine, ${ }^{1}$ However, with regard to his ecclesiology, some factors should be memtioned. Augustine had an intellectual brilliance which was recognized in his youth, and so was sent away to be trained to be a teacher of rhetoric in nearby Carthage. Never having been baptized a Christian, Augustine had an intellectual curiosity for other world-views and soon feel into a circle of Manicheans in that city. This group felt that man was a hopeless pawn between the forces of good and evil which were engaged in continual warfare. Upon leaving Carthage, he traveled to Italy to take up tenching. His curiosity remainod, hovever, and as he drew away from the hopelessness of Manichees, finding them shallow, he became increasingly attracted to Middle

Platonism, then in inteliectual fashion jn the Empire. By this time, he had token a concubine who hore him a som, Adeodatus, his career as a teacher was then at its height. 
At about this time, Augustine found himself yearning to study Christianity. After temporizing for more than a year, he was baptized in 387 at age 33 by his mentor, St. Ambrose of Milan. Ambrose was a scholar in his own right, but his continual commitment to scripture commended itself to his new convert, who withdrew from the world and his concubine, with a circle of friends, to read, discuss and live scripture. His works written at the time of his conversion show a deep attachment to Neo-Platonism, which he combined with his Christianity. Upon arrival in Hippo, he founded a monastery for the same purposes as the circle in Italy, but was interrupted in that life by the demands of his congregation that he become a priest. Eventually he became coadjutor and then full bishop of Hippo (c. 395).

It was at this time that the African Church was being strongly challenged by the Donatists, a schismatic sect which held itself to be the true Church as opposed to their Catholic brethren. The controversy arose out of the last persecution of Christianity in the Empire, that of the Emperor Diocletan. There were certain Christians, including priests, who, under threats or torture, delivered up the sacred books to the state. When the persecution ended, the election of Caecilian to the See of Carthage (311) was challenged on the grounds that he was a "traditor," one who delivered up the books. The dissidents held their own council which deposed Caecilian and a schism was on. The name of the sect is derived from its greatest polemicist, Donatus, a figure in the original controversy. When the Emperor Constantine supported Caecilian, the Donatists appealed directly to him to hear their case. Again they were denied. After pacification failed, force was used, but failed to halt the growth of the sect which declared itself to be the 
"church of the pure." It also declared that any sacrament received from a sinner was void; therefore, Catholic converts to Donatism had to be rebaptized. The sect had social strength in that it was primarily a North African church which spoke Punic, rather than Latin, and was oriented to Africa rather than Rome. Encouraged by the Emperor Julian the Apostate (361-363), it was a formidable enemy at the time Augustine succeeded to the Episcopate.

Augustine engaged himself in a series of debates and polemical tracts against the Donatists during this period (395-412). These works form the core of his ecclesiology, and it is this period upon which this paper will concentrate with regard to Augustine.

After the failure of Donatism, a new crisis arose. The interplay between faith and works was studied by a British monk named Pelagius who asserted that man was capable of perfection without the grace of God. The final period of Augustine's life (412-430) was devoted to the refutation of Pelagius, to his followers, and to the formulation of his concepts of predestination -- concepts so subtle and brilliant that they formed an intellectual crown for an extraordinary life.

\section{B. The Names of the Church}

It is not surprising that Augustine makes frequent use of symbolism in his ecclesiological references. His theory of symbolism centers around the use of language or other forms of communication as mere representations of a greater reality, for which they act as signs. Scripture is, as the Word of God, the ultimate source of reality, and, in turn, is the source for all moral precepts and aesthetic creativity. ${ }^{2}$ 
It is Scripture, then, to which Augustine first turns to refute the Donatists and to demonstrate the beauty of the Body of Christ.

Augustine relies heavily upon Scriptural symbolism to explain certain qualities of the Church. During no period in his life did he believe that mere membership in the Church was the only requisite for salvation, nor did he regard that body as a community of saints. However, membership was, for him, necessary for salvation.

The Church was often compared by Augustine to the Jews of the 01d Testament, the people cared for and chastened by God. 3 As His people, its members could receive His inheritance of eternal life through the Incarnation. ${ }^{4}$ This community of Christ thus entered into a New Covenant, superceding and fulfilling the old Covenant:

The true Judea, then, is the Church of Christ, believing in that King, who hath come out of the tribe of Judah through the Virgin Mary. . . . For of Judah is David and out of David is the Lord Jesus Christ. We believing in Christ do belong to Judah and we acknowledge Christ. . . The true Sion is the Church of Christians. 5

The human quality of the Church as a real part of the earthly world is stressed in the symbol of the Church as pilgrim. Though he finds the mission portion of the Church to be heavenly, Augustine compares the Church to the traveller through the wilderness of the world, strengthened by the nourishment of Christ. ${ }^{6}$ The travail will continue through all time:

For the voice is that sweet voice, so well known to the ears of the Church, the voice of our Lord Jesus Christ, and the voice of His Body, the voice of the Church toiling, sojourning upon earth, living among the perils of men speaking evil, and of men flattering. $7^{\circ}$

The relationship of Christ to His people is similarly compared to that of a physician aiding the sick. For Christ is solicitous of His 
Body and, like a surgeon, will cure the sick portions and leave the remainder. ${ }^{8}$ The fact that some patients do not respond is of little importance:

You will say that to some these remedies are of no service. Is the art of healing, therefore, to be abandoned, because the remedy of some is incurable?

The health of the Body of Christ is the unity of its members in charity. The communal need for unity in charity is necessary for the spiritual health of the individual members:

But whatsoever groweth cold in charity, is become enfeebled in the Body of Christ. But he who already exhalteth our Head, is able also to make even the feeble members whole; provided, that is, that they be not cut off by excessive impiety, but adhere to the Body until they be made whole. For whosoever adhereth to the Body, is not beyond hope of healing; whereas that which hath been cut off, can neither be in process of curing, nor be healed. 10

The church is also given the analogy of ship, or ark, by Augustine due to its safety from the waters of the world which would engulf those on board. On two occasions, he has reference to Christ's voyage across the Sea of Galilee (Matt. 8: 23-27). At one time, he uses the passage as advice to the church to recall its dependence on Christ:

Keep thyself therefore in the ship, and pray to God. For when all counsels fail, when even the rudder is unserviceable, and the very spreading of the sails is rather dangerous than useful, when all human help and strength is gone, there remains only for the sailors the earnest cry of entreaty, and pouring out of prayer to God. He then who grants the sailors to reach the haven, shall so forsake His own Church, as not bring it on to rest? 11

At another time, the passage is used in an existentialist and apocalyptic manner in a stunning display of rhetorical power:

- . As the end of the world approaches, errors increase, terrors multiply, iniquity increases, infidelity increases; the light in short, which by the Evangelist John himself, is fully and clearly shown to be charity . . . that light, I say, is very 
often extinguished; this darkness of enmity between brethren increases, daily increases, and Jesus is not yet come. How does it appear to increase? "Because iniquity will abound and the love of many will begin to wax cold." Darkness increases, and Jesus is not yet come. Darkness increases, love waxing cold, iniquity abounding, --these are the waves that agitate the ship; the storms and the winds are the clamors of revilers. Thence love waxes cold; thence the waves do swell, and the ship is tossed. 12

While the difficulties of the Church are realized by Augustine, nevertheless, he finds that, in Christ, the necessary stability for the carrying on of her mission is to be found. Christ is the rock on which the Church derives her strength to proceed. ${ }^{13}$ Further, the idea of rock is utilized in the Mosaic sense (Ex, 17: 1-7 and I Cor, 10:1-4) of a source of nourishment through divine action. ${ }^{14}$ Matt. 16: 16-19 also plays a significant role in Augustinian ecclesiology. In his treatment of this passage, Augustine states:

. . On this rock, therefore, He said, which thou has confessed, I will build my Church. For the Rock, (Petra) was Christ. . . . The Church, therefore, which is founded in Christ received from Him the keys of the kingdom of heaven in the person of Peter, that is to say, the power of binding and loosing sins. For what the Church is essentially in Christ, such representation is Peter in the rock (Petra); and in this representation Christ is to be understood as the rock, Peter as the Church. This Church, accordingly, which Peter represented, so long as it lives amidst5 evil, by loving and following Christ is delivered from evil....

Therefore, the Church, insofar as it is founded and sustained by Christ, will survive the perils of this earthly life, and, at the same time, receive continuous nourishment from its foundation, so long as it loves and directs itself towards the same.

Another reference which occurs often in Augustinian ecclesiology is the comparison of the relation of Christ and the Church to that of Bride and Groom. Through a "great mystery," the Church and Christ are made one flesh, formed by transformation; as Adam slept and Eve was 
formed from a rib of his side, so the death of Christ formed the Church as the mystery flowed from his side with the water. ${ }^{16}$ often these sexual overtones are combined with passages from the Song of Solomon:

These words which I have quoted out of the Holy Song of Songs, of a kind of bridal song of the bridegroom and the bride (for it is a spiritual wedding, wherein we must live in great purity, for Christ hath granted to the Church in spirit that which His mother had in body, to be at once a Mother and a Virgin.) 17

The love between bride and bridegroom is one which lacks carnal connotations, but it requires the beloved to aid the lover in His efforts to reach her, an attitude not inconsistent with Augustine's theory of grace:

- He knocks, therefore, to shake off this quiet from his inactive saints, and cries, "Open to me," thou who, through my blood, are become "my sister"; through my drawing nigh, "my neighbor"; through my Spirit, "my dove"; through my word which thou has freely learned in thy leisure, "my perfect one": open to me, go and preach me to others. For how shall I get into those who have shut their door against me, without someone to open? And how shall they hear me without a preacher? 18

While the Church showed a close relationship with Christ, its members are not to be identified with His elect, for such would be an endorsement of the Pelagian notion that one could will his awn salvation through mere external membership in the Church. In speaking of those elect, in the City of God, Augustine notes the fickleness of the faithful who attended church one day and the theater the next; these symbolize the admixture of the cities of Jerusalem and Babylon throughout history. 19 Speaking of the nature of the City of God, Augustine identifies it once with the Church, which, in this context, is to be understood to mean those in the Church who are also regenerated by grace. The remainder are a . burden which the Church must bear throughout its earthly travail. These elect are the new people of God:

- But now that it is clear that Sion is the city of God, what is the city of God, but the Holy Church? For men who love one 
another, and who love their God who dwelleth in them, constitute a City unto God. Because a city is held together by some law; their very law is love; and their very love is God; for openly it is written, "God is Love." He therefore who is full of love, is full of God; and many, full of love, constitute a city full of God. That City of God is called Sion; the Church therefore is Sion. 20

However, the most common analogy used for the Church is that of the Body of Christ (Co1. 1: 18, 24; Eph. 1: 23, 2:16, 4:4). He explains this analogy in these terms:

- . The fullness of Christ, then, is head and members. Head and members, what is that? Christ and the Church. . . . For the head shows that the members may see, and the head teaches that the members may learn; nevertheless one man, head and members. 21

Christ sees the sins of the members of His body, and ever encourages them to reform, as He called Paul near Tarsus. ${ }^{22}$ The response to the call of God, or reform, is accomplished by recalling membership in His Body and following the example of the Head. ${ }^{23}$ The Apostles saw the Head in Christ and believed, while the member is called upon to view the Body and believe in the Head. ${ }^{24}$ Through the mediation of Christ as Head of the Church, members are sanctified in truth as He sanctifies Himself for their sake. 25 By approaching Christ "on feet of Charity," they respond to His call and exhortation to be relieved of the burden of the cares and sins of this world through the ritual reception of His Body and Blood. 26 The Head and members "are Christ," gathered together in a "great sacrament" (that is, a dispensation of grace) which delivers the participants from their present helplessness. 27 Yet, not all those seeming or desiring to be delivered, are so delivered. In commenting on Luke 8:45, wherein Christ asks who in the throng touched Him, Augustine states:

-. In this case also is His Body now, that is, His Church, The faith of the few "touches" it, the throng of the many "press" it. . . . It is pressed by many, touched by few. The flesh presseth it, faith touches it. . . 28 
The emphasis, therefore, is that Christ is to be sought through the spirit. Yet, many of these writings emphasize the necessity of unity through Charity to maintain one's membership in the Body. He who gives scandal by leaving the Body cannot live: "How is he in Christ who is not in the body of Christ?" 29

Other terms are used to represent the church in the writings of Augustine. One is the figure of the dove ${ }^{30}$ who knows her own and symbolizes purity and unity through the Holy Spirit. Another is the figure of the Inn of the Good Samaritan to which the beaten traveller is brought gratuitously to be restored to health. 31 Similarly, the use of the analogy of the Church as a building, built from a cornerstone which the builders rejected, is used on two occasions. 32

One final name is of interest: that of the comparison of the Church to a mother. She is a "spiritual mother" who gives "life and nourishment" ${ }^{33}$ to her members, a mother prefigured in Eve, mother of all the living, ${ }^{34}$ who groans in the travails of giving birth to her children. 35 Man is compared to a child who needs, during his infancy, the milk of the Word, before his growth:

- . Now His mother is the Church; and her breasts are the two Testaments of the Divine Scriptures. Hence let him suck the milk of all the things that as signs of spiritual truth were done in time for our eternal salvation, that being nourished and strengthened, he may attain to the eating of solid meat, which is "In the beginning was the Word, and the Word was with God, and the Word was God." Our milk is Christ in His humility; our meal, the self-same Christ equal to the Father. . . 36

As each of the names of the Church indicate, man must be dependent on the grace of God for spiritual survival. Such survival, according to Augustine, could come only through the Covenant-Partner of God, the Church. 


\section{The Church and Her Members}

The binding force of Charity as the cement which holds the Church together has been touched upon above and will be repeated in the discussion in Chapter III of the Augustinian attribute of the holiness of the Church. During the Donatist controversy, Augustine remained willing to be in communion with those who held for the necessity of rebaptism, despite the error he attributes to them, if they would not cut themselves off from the bonds of charity, which charity is able to cover a multitude of sins. ${ }^{37}$ That charity came from God and is unavailable to those who are not His People. This peace or charity, therefore, does not exist in schism or heresy, for a schismatic lacks the peace and unity which comes to the life of the good man through constant reform, rather than mere baptism. ${ }^{38} \mathrm{~A}$ heretic cannot possess it at all. In an extensive work on the subject, Sermon 21 on Matt. 12:32, touching upon the Sin Against the Holy Spirit, Augustine makes the following points concerning the necessity of Church unity in Charity.

1. The Holy Spirit, not the Church, forgives sins.

2. The Sin Against the Holy Spirit is a lack of response to reform.

3. The schismatic heretic or deceitful man or sect does not have the Holy Spirit, which "flees deceit" and rejects him as Abraham did Ishmael for Isaac.

4. The "Form of Godliness" of baptism is of no effect on they who cut themselves off from the Church and lack the Spirit. Their sins return inmediately.

5. He who is not with Christ is against Him and scatters, rather than sows. A deliberate rejection of unity is a sin against the Holy Spirit, who is undivided and who uni- fies the Church. Such unity is based entirely on His Spirit, rather than any personality in the Church. (I Cor. 3: 4,5 .) 
The subjective intention of the person cut off from the Church is important to Augustine, but is treated to a lesser extent as he grows older. In On True Religion, written in 390 , four years after his conversion, Augustine admits (Chapter 6) that the carnal man can drive a good man outside the Church, and the good man may be justified, albeit a rare occasion. In his Anti-Donatist writings, he does not pose such a question, merely stating that one who cuts himself off from the Church in ignorance, sins to a lesser extent. 39

His use of the names of the Church indicates that Augustine viewed the Church as a corporate being, an entity apart from its members. While he found praise for the Church, he found that the membership of that body was not, on that account, so deserving. At the outset, he fulminated anathema to those seeking to go their own way outside the community of the faithful, finding he who was not with the Church, as with Christ, was against her. ${ }^{40}$ The presence of carnal and spiritual are found in her ranks, to be separated on the last day. As Christ told his Apostles after His Resurrection, "Do not touch me," so the Church is not to seek him carnally, but spiritually by faith. ${ }^{41}$ on at least two occasions, he compares the Church to heaven and the remainder to earth, as here:

- . Thus again, "Thy will be done as in heaven, so on earth," may be well understood, by making "heaven" to be the Church, because it is the throne of God; and "earth" the unbelievers, to whom it is said, "Earth thou art, and unto earth shalt thou go." . .42

Although Augustine spoke mainly of the post-Resurrection people of God, he did not exclude the Children of Abraham who lived before Christ from their ranks, Thus, he said:

- But the Church, which is the people of God, is an ancient institution even in the pilgrimage of this life, having a carnal 
interest in some men, a spiritual interest in others. To the carnal belongs the old Covenant, to the spiritual, the new.

But he continued, stating that there were those born into the o1d Covenant who were spiritually inclined, presumably Abraham, Isaac, Moses, etc., while there were others born into the New Covenant who were carnal in nature; thus it mattered less into which covenant one was born than whether he was carnally or spiritually inclined. Therefore, by no means was the post-Resurrection Community of Christ to be identified with the elect. 44

One of the most extensively used themes in describing the interrelationships among members of the Church in the works of Augustine is that of wheat and tares separated on the threshing floor on the last day. Again, the most common occasion for this analogy is the Donatist controversy. In a typical passage, after refuting the Donatist claim on historical grounds, Augustine continues:

We rely, however, not so much on these documents as on the Holy Scriptures, wherein a dominion extending to the ends of the earth among all nations is promised as the heritage of Christ, separated from which by their sinful schism they reproach us with the crimes which belong with the chaff on the Lord's threshing floor, which must be permitted to renain mixed with the good until the eng ${ }_{45}$ come, until the whole be winnowed in the final judgment. . .

They who remain in the Church outwardly for motives not of God will similarly be judged:

- . Who are they that se11 sheep and doves? They are they who seek their own in the Church, not the things that are Christ's. They account all a matter of sale, while they will not be redeemed: they have no wish to be bought, and yet they wish to se11. . . .46

However strong were his convictions with regard to Church members, Augustine uses this analogy of the threshing floor with even more telling force in applying the same to Church leaders. He found two types of 
these - those who seek Christ and those who seek the world. The 1atter, who will exist for all time, may cause others to grow cold in charity, but the Word will save if followed by Church members despite the bad example of leaders. ${ }^{47}$

In his polemical thrusts against the Donatists, Augustine uses the harvest analogy to illustrate the mission of the Church in time. In speaking to the Donatists, he asserts:

- . He (Christ) said, "Let both grow together till the harvest"; He said, "The field is the world"; He said not, "The field is Africa." He said, "The harvest is the end of the world"; He said not, "The harvest is the time of Donatus." $\mathrm{He}$ said, "The reapers are the ange1s"; He said not, "The reapers are the captains of Circumcilliones." 48

The evil who remain in the Church and partake of its sacraments do not gain anything by such participation and are merely endured by the Church until the time of judgment. ${ }^{49}$. Since rebaptism was a major facet of the Donatist controversy, Augustine studied the administration of the sacraments at length and concluded that since the Church contained a mixture of good and evil men, the sacraments do not depend on the administrator, but on Christ, from whom they flow:

- . when a bad man administers baptism, through the ignorance or forbearance of the Church (for bad men are either not known as such, or are borne with; this chaff is tolerated until the floor is fully purged at the last), that which is given is one, not unlike because the ministers are unlike, but like and equal because "This is $\mathrm{He}$ that baptizeth." 50

Though there were heroes and grave sinners in the Church, ${ }^{51}$ there is no place therein for hypocrisy:

- . It therefore follows that he who is least in the kingdom of heaven, as the Church now exists, sha11 not enter the kingdom of heaven, as the Church shall be hereafter. . . .52

For the 1ife of the Church member, as we have seen, is not one whose obligations end with formal baptism. Such a life consists in the 
constant renewal and reform of one's life. ${ }^{53}$ This renewal is best achievable in community, rather than individual1y. ${ }^{54}$ The theme of the Church as mother and as Body of Christ, giving nourishment to the individual believer is reinforced by Augustine's constant emphasis on community -- the community bears one another's faults and sins, upholds and is upheld. Though Augustine was aware of the Anchorites, he finds no real use for their example. Like Aristotle's earlier dictum restated, the man who chose to stay outside the ecclesiastical community was a fool or a savage. Nor was the community infected by heresy and sin, even when a large number of its members were so infected. It continues its journey, renewing itself in the Lord. For if sin could irretrievably harm the Church, then it no longer existed:

- . where is the Church, which, according to these words, must be held to have perished from that very moment by the contagion of their sins [those of the alleged traditores]? But if, as is the most fimly established truth, the Church has remained and does remain, the partaking of the sins of others, which is forbidden by the Apostle, must be considered only to consist in consenting to them. $55^{\prime}$

Within the Church, Augustine discerned an array of talents which could be utilized by her to do her mission of spreading the Word. Al1 members take part in this work, albeit differently:

- In the body are divers members: this member can do one thing, that another. God hath comparted the Body together, He hath not given the ear to see, nor the eye to hear, nor to the forehead to sme11, nor to the hand to taste; he hath not given them these functions; but to all members hath He given soundness, hath given union, hath given unity, both of His Spirit quickened and united all alike. . . 56

Thus, the Spirit gives charity throughout the Church, joining the divers gifts or charisms together for the love of Christ. "'For the spirit is given,' as the Apostle saith, 'to manifestation. ". 57 Yet in ordering these gifts, a hierarchy follows therefrom: 
- . For there is in the church this order, some go before, others follow; and those who go before make themselves "an example" to those who follow; and those who follow imitate those who go before. . . .58

The connecting thread through the charisms, uniting them, is love. This love enables each member to free himself from the world in virginity without regard to marital state. ${ }^{59}$ Thus members perfect one another and are in turn perfected in and through the Church to which they give of their gifts.

It is through the Church that the Sacraments flow to the recipient. The Sacraments were another area which Augustine found necessary to examine by the Donatist controversy. He concluded that, contrary to Donatist teaching, their efficacy does not depend on the state of the minister, since they come from God though they may be misused. ${ }^{60}$ The Sacraments aid one in following the road to Christ, but must be combined with constant renewal:

- . Now forsooth all are reckoned the people of God, who carry His Sacraments, but not a11 belong to His mercy., A11 forsooth receiving the Sacrament of Baptism of Christ, are called Christians, but not all live worthily of that sacrament. . .61

The Sacraments flow from the side of Christ ${ }^{62}$ and bind the wounds of the faithful. 63 For those in schism, though they hear and handle valid sacraments, their lack of charity prevents the same from being efficacious. ${ }^{64}$ It is only for those who live in love that the sacraments can be meaningful. And it is only those members of the Church in unity therewith who axe able to live in such love. Let us examine the effects of such membership more closely. 
D. The Effects of Church Membership

As discussed above, according to Augustine the individual

Christian lives his spiritual life in a community bound together by charity. The elect are within her fold, but that is not to say that these are free of the perils of sin and temptation as is demonstrated in the figure of Peter:

Let us, looking at ourselves in this member of the Church, distinguish what is of God, and what of ourselves. For then we shall not totter, then shall we be founded on the Rock, shall be fixed and firm against the winds, and storms, and streams, the temptations, I mean, of the present world. Yet see this Peter, who was then our figure; now he trusts, and now he totters; now he confesses the undying, and now he fears lest he should die. Wherefore? because the Church of Christ hath both strong and weak ones; and cannot be without strong or weak; whence the Apostle Paul says, "Now we that are strong ought to bear the infirmities of the weak." In that Peter said, "Thou art the Christ, the Son of the living God," he represents the strong: but in that he totters, and would not that Christ should suffer, in fearing death for Him, and not acknowledging the Life, he represents the weak ones of the Church. In that one Apostle, then, that is Peter, in the order of the Apostles first and chiefest, in whom the Church was figured, both sorts were to be represented, that is, both the strong and weak; because the Church cannot exist without them both.65. [Emphasis supplied.]

It is through grace that the members of the community of Christ aid one another in unity and are given the wool to wear the garment of the Church which will be as a Bride, without spot or wrinkle, presented to Christ the Bridegroom. Those who are perverse within the community are to be endured, as Christ bore Judas. ${ }^{66}$ Yet there are many who are not perverse, but who sin and thus the "servants of sin" as "many sinners enter the Church" but these are in hope that the Son will free them of their sins and make them His servants: "for we were the servants of lust; but being set free, we are made the servants of love." ${ }^{67}$ The Lord sets his servants free; His salvation and call to reform is reflected in His Church which mystery can be seen only "through a glass dark1y." 68 
This reflection is a continuation of the saving work of Christ continued through the Church, which bears witness to Christ as the Apostles bore witness:

- . This the disciples did not yet see: they did not yet see the Church through all nations, beginning at Jerusalem. They saw the Head and they believed the Head touching the Body. By this which they saw, they believed that which they saw not. We too are like to them: we see something which they saw not and something we do not see which they did see. . . The sight of Christ helped them to believe the future Church; the sight of the Church helps us to believe that Christ has risen. Their faith was made complete, and ours is made complete also. Their faith was made complete from the sight of the Head, ours is made complete by the sight of the Body. Christ was made known to them "wholly" and to us $\mathrm{He}$ is so made known: but he is not seen "wholly" by them, nor by us has He been "wholly" seen. By them the Head was seen, the Body believed. By us the Body has been seen, the Head believed. Yet to none is Christ lacking: in all He is complete though to this His Body remains imperfect. . . .69

The present Church is a continuation of a divine Covenant between God and man which began with Abraham: "Then it was not seen, and was believed: now it is seen and it is contested; and what was then said to one man, and was by that one believed, is disputed by some few, when in many it is made good." 70 This continuous covenant has had different manifestations in the times of Abraham, Moses, Christ and the contemporary Church of Augustine. Thus, while miracles were needed in the 01d Testament and at the time of Christ, they are no longer needed, the Church having been established and the constant expectation of outward signs causing the heart to grow cold towards inward matters. 71 Those who cut themselves off from the covenant deny the same and are antiChrist, which is a figure of denial, and lead the third and final persecution of the Church after the Romans and false brethren. ${ }^{72}$ But the Lord will remain with the Church throughout a11: 
Antichrists are heretics and schismatics who go out from His Body and are contrary to it. They go out from it and its health is better. ${ }^{73}$

One of the most intriguing questions to students of Augustine is his endorsement of the use of force against heretics (in his case, the Donatists). This idea came later in life, for, as he thought in earlier life, persuasion was more effective. Yet to break the hold of evil, he felt that additional means were necessary to penetrate hardness of heart. He found that the enemies of the Church (whom he described as "Jews, heretics and pagans") conspire against the unity of the Church, so therefore, where Christians have the power, they have the duty to pull down the idols of error. ${ }^{74}$ The philosophy of such compulsion is outlined in a Treatise Concerning the Correction of the Donatists, a letter (Ep. 185) to Boniface, Count of Africa. In this letter, Augustine sets forth his belief that the Catholics cannot desext their erring brethren, but must "compel them to come in" (Luke 14:22, 23) like a father chastening his erring sons out of love. Augustine does not fear using the Emperor to promulgate laws which are to be feared and obeyed, rather than evil laws to be resisted. He argues, on the basis of Ga1, 4:22-31, that the Church, like Sarah in the 01d Testament, has the right to keep discipline. Finally, the persecution of the Donatists is not to be equated with former persecutions of the Christians:

- . If, therefore, we wish either to declare or to recognize the truth, there is a persecution of unrighteousness, which the impious inflict on the Church of Christ; and there is a righteous persecution, which the Church of Christ inflicts upon the impious. She therefore is blessed in suffering persecution for righteousness sake; but they are miserable, suffering persecution for unrighteousness. Moreover, she persecutes in the spirit of love, they in the spirit of wrath; she that she may correct, they that they might overthrow; she that she might recall from error, they that they might drive headlong into error. . . 
An outward distinction between the two persecutions is that persecution by the Church does not include death or maiming, but is based on correction. ${ }^{75}$ Kings serve God by legislating against impiety so that compulsion is justified by that end. Such compulsion is useless without penitence or reform and Augustine recognizes the uselessness of an outward return, but hopes that the use of force to prevent a negative result (the spread of heresy or schism) will facilitate the mission of the Church in urging reform. ${ }^{76}$ His endorsement of the use of civil force is also justified in Rom. 13:1-4, which states that all power is of God and that "our help is in the name of the Lord"; similarly, however, he urges Christians not to loose revenge for Donatist outrages but to have a state of mind which is the requisite in this otherwise distasteful enterprise. ${ }^{77}$ other authority for such correction includes the correction of the bondswoman by Sarah in Gen. 21: 10, and Ga1, 4: 29, Moses' correction of the Jews in Dan. 9: 3-20, the love of the Lord for those He chastizes in Proverbs 3: 12, the same in I Cor: 11: 32 and Heb. $12: 6 .^{78}$ Augustine concluded that this persecution had a salutory result:

. . Was it my duty to be displeased at the salvation of these men, and to call back my colleagues from a fatherly diligence of this kind, the result of which has been, that we see many blaming their former blindness? ${ }^{9}$

The power of the Church to cure heresy and schism is also based on the power to bind and loose in maintaining internal discipline. This power is given to the Church (as distinguished from Baptism which is of God and may be administered by a11) for its use in the world to forgive men. ${ }^{80}$ He elaborates: 
- . If this (Matt. 16: 19) was said only to Peter, it gives no ground of action to the Church. But if such is the case also in the Church, that what is bound on earth is bound in heaven, and what is loosed on earth is loosed in heaven, --for when the Church excommunicates, the excommunicated person is bound in heaven; when one is reconciled by the Church, the person so reconciled is loosed in heaven: - -if such, then, is the case in the Church, Peter, in receiving the keys, represented the holy Church. . .81

With this power, the Church keeps discipline and concord among her members. The use of discipline provoking fear is believed by Augustine to be compensated in the catharsis engendered, provoking the recalcitrant to reform and self-examination.

Similarly, the nature of the Church is such that he who wilfully separates himself from her is unable to do any good. Those separated from the Church can receive the same sacraments as those within, but they are of no effect, though they may otherwise be valid; unless he holds an erroneous conscience, one outside the Church cannot be saved and his acts profit him nothing. ${ }^{82}$ He adds:

- We speak, brethren what ye know: how many seem to do good works without the Church? . . . How many works may heretics do not in the church; they place not their young in a nest. They shall be trampled on and crushed: they shall not be kept, shall not be guarded. . . 83

\section{E. Summary}

Augustine used many images to signify the Church, but the common denominator from these signs is that the Church is the continuing witness to Christ and the dispenser of His grace. It occupies a special relation with God and played a central role in the continuing mediation of Christ through the Incarnation. While it contains a mixture of good and bad, the corporate being is part of the Body of Christ and is therefore unequivocally good, despite individual acts of its members. 
The Church, according to Augustine, requires that Christians be one with it, so the individual needs and gifts could be brought to her. She distributes grace through the Sacraments to those who possess charity from God, but is unable to aid the remainder. To aid the latter, and to keep order within herself, the Church kept instruments of discipline and accepted the aid of the civil powers in fulfilling her mission. The Church, as an institution, is a necessary vehicle for salvation and all men must belong to her for that purpose.

Perhaps this view is jaundiced by the numerous attacks upon and internal dissensions within the African Church. Nevertheless, Augustine never failed to $100 \mathrm{k}$ to the inward motivation of the Church member and attaches, and never failed to require, love of al1 Church as we11 as a11 human actions. 
FOOTNOTES: CHAPTER I

1. Perhaps the best biography is by Peter Brown, Augustine of Hippo, University of California Press, Berekeley, 1967.

2. Colish, Marcia, The Mirror of Language, Yale University Press, New Haven, 1968, pp. $8-82$.

3. Ep. 23. A11 citations from Augustine are from The Nicene and PostNicene Fathers, ed. Philip Schaff, Cushing-Mallory, Ann Arbor, 1956. According to I, Sacranentum Mundi, 314, "Church," the fathers used many of the same symbols to illustrate the nature of the Church. Some common ones were: people, vineyard, body, temple, house, flock, kingdom, field and net. As a common basis they found the Church to include (a) the Holy Spirit and the Eucharist, (b) the spiritual maternity of the Church, (c) charity and concord among local churches, (d) collegiality of episcopate, and (e) the Papacy as "guardian of charity" of the Universal Church.

4. Enn. on Psalm 5.

5. Enn. on Psalm 86. See a1so Enn. on Psalm 149.

6. Tractate 28 on John 7: 1-13. See also Tractate 124 on John 21: $19-25$.

7. Enn. on Psalm 58.

8. De Baptismo Contra Donatistos (hereinafter referred to as "De Baptismo"), Book I.

9. Ep. 93. See also A Treatise Concerning the Correction of the Donatists (hereinafter referred to as "Correction of the Donatists") (Ep, 185).

10. Sermon 87 on John 10.

11. Sermon 25 on Matt. 14:24.

12. Tractate 25 on John $6: 15-44$.

13. De Baptismo, Book IV.

14. Tractate 26 on John 6:41-59; Tractate 28 on John $7: 1-13$,

15. Tractate 124 on John 21:19-25. See a1so Enn. on Psa1m 40.

16. Tractate 9 on John $2: 1-11$. See a1so Sermon 41 on Matt. 24:42, Sermon 79 on John $5: 39$. 
17. Sermon 88 on John $10: 14$. This sermon is a polemic against the Donatists. In Homily 2 on John $2: 12-17$, a similar approach is taken: . . Concerning the Bride, let us see what he saith; that thou, when thou knowest the Bridegroom and Bride, mayest not without reason come to the marriage. For every celebration is a celebration of marriage: the Church's nuptials are celebrated. The King's son is about to marry a wife, and that King's son is himself a King: and the guests frequenting the marriage are themselves the Bride. [In Tractate 9 on John $2: 1-11$, Augustine states that a11 who live in actual or virtual virginity, marry Christ.] Not, as in a carnal marriage, some are guests, and anothex is she that is married; in the Church they that come as guests, if they come to good purpose, become the Bride. For all the Church is Christ's Bride, of which the beginning and first fruits is the flesh of Christ: There was the Bride joined to the Bridegroom in the flesh.

See also Concerning Faith of Things Not Seen.

In On Continence, Augustine uses the Pauline charge to husbands to love their wives as Christ loves the Church (Eph. 5:29) as a departure point to demonstrate the intimate relation between the Church and its Bridegroom. See also On the Good of Widowhood.

18. Tractate 57 on John 13:6-10. Augustine elaborates on this in the same work in stating that, while it is better for Christians to ignore things of the flesh, preachers must use the flesh to spread the word. In view of his tremendous intellectual and rhetorical gifts, Augustine probably applied this exemption to himself.

19. De Civitate Dei, Book I, 35. Letters against Petilian.

20. Enn. on Psalm 99. Yet Augustine urged that the Church should pray for Her enemies, even as Christ did from the cross, despite the misfortune which would meet their contumacy. Sermon 6 on Matt. 6:9.

21. Tractate 21 on John 5:20-23. The love of Christ, therefore, without merit, accrues to the members of His Body, that, as Christ prayed in the Garden of Olives for the love of God in them. Tractate 111 on John 17:24-26.

22. Enn. on Psalm 38. The instruments of reform are the Sacraments. Sermon 79, on John 5:39; De Civitate Dei, Book 22, 17.

23. Sermon 87 on John 10 .

24. Sermon 66 on Luke $24: 36$.

25. Tractate 108 on John $17: 14-19$.

26. Enn. on Psalm 34; Enn. on Psalm 58.

27. Enn. on Psalm 55. 
28. Sermon 12 on Matt, 8:8 and I Cor, 8:10.

29. Homily 1 on I John 1:1-11. This homily is an extended antiDonatist polemic. Augustine regarded their schism as a sin worse than idolatry. Ep. 51. In On Continence, Augustine warns against a Manichean hatred of the flesh and subsequent dislike of the name of the Church as the Body of Christ, finding no inherent evil in the flesh or in sexual contact. This same warning against such dislike applies to the Bride-Bridegroom relationship discussed earlier.

30. Tractate 6 on John 1:32, 33, states: ". . . by this authority, I say, stands the unity of the Church, which is figured in the dove, concerning which it is said, 'My dove is one, the only one of her mother." The doves are further identified as "those who seek Christ" compared to the raven sent forth from the ark, which did not return, seeking rather its own. See also De Baptismo, Book V.

31. Sermon 81 on John 6:53. In On Man's Perfection in Righteousness, Chapter 15, Augustine utilizes Rom. 8:30 as the basis for an antiPelagian polemic. The Church, upon the last day, will be presented to Christ "without spot or wrink1e." Some of the spots suffered by the Church include its involvement in evils and offences, its admixture of good and evil, and its close relationship to the political realm, but these are purged through a washing out by the word. See also, Against Two Letters of the Pelagians, Ch. 17; On Nature and Grace, Ch. 23; On Christian Doctrine, Ch. 16.

32. Tractate 9 on John 2:1-11; Sermon 39 on Matt. $21: 19$ and Luke 24:28,

33. Ep. 34, See also, On Forgiveness of Sins and Baptism, Ch. 38; On Nature and Grace, Ch, 23.

34. Enn. on Psalm 41.

35. Tractate 101 on John 16:16-23. This theme is not without indications of divine selection. In Tractate 11 on John $2: 23-25$ and $3: 1-5$, Augustine compares those in the Church to Essau and Jacob, the ones hated and loved by Rebecca, stating "and one womb carries them until they are separated in the end: and the good cry out against the evil, and the evil in turn cry out against the good, and both strive together in the bowels of one mother. . . ."

36. Homily 3 on I John $2: 18-27$. This theme is repeated in Ep. 23 in which Augustine described the Church as "true mother, who to all nations both offers a we]come to her bosom, that they may be regenerated, and gives a mother's nourishment to then when they are regenerated." See a1so, On the Creed, A Sermon to the Catechumens. 
37. De Baptismo, Books I and V: In Ep. 53, Augustine derided the Donatists for their hypocricy in participating in the kiss of peace without the intention of charity.

38. De Baptismo, Books I, III and IV. In Book III, Augustine quotes St. Cyprian, who allowed rebaptism rather than split the unity of the African Church, to the effect that he did not judge the actions of those who rebaptized, leaving it to Christ. He concluded that no Church position had then been taken on rebaptism, despite the diversity of views on the subject. Since that time, it had been condemned. While he clearly regards their actions as heretical, Augustine states throughout that, for the sake of charity, he would remain in communion with the Donatists. In Tractate 6 on John $1: 32,33$, Augustine notes that devils believe, but lack charity, and compares them to the Donatist sect, who have the outward trappings of Christendom, but no efficacy.

39. De Baptismo, Book IV.

40. Op. Cit., Book IV.

41. Sermon 93 on John $16: 7$.

42. Sermon 8 on Matt. 6. In Sermon 7 on Matt. 6, Augustine states, ". . . the Church of God is heaven, His enemies are earth." In Enn. on Psalm 26, he finds the words "I have loved the beauty of your house" to refer to the Church, thus again comparing the corporate person of the Church to something of divine beauty.

43. De Baptismo, Book I.

44. Ibid.; Book 6 .

45. Ep. 53. See a1so Ep. 23; Enn. on Psalm 120; Sermon 21 on Matt. 12: 32; Tractate 27 on John 6:60-72; De Civitate Dei, Book 18, 49.

46. Tractate 10 on John $2: 12-21$.

47. Ep. 208.

48. Ep. 76 .

49. De Baptismo, Books IV and VII. In the latter, Augustine is more explicit: ". . For salvation is peculiar to the good, but the sacraments are common to the good and bad alike." See also Sermon 21 on Matt. 12:32; On Patience.

50. Tractate 6 on John 1: 32, 33 .

51. "In the Church of God, thou findest an abyss, thou findest also mountains; thou findest there but few good, because the mountains are few, --the abyss broad." Enn. on Psalm 36. 
52. Tractate 122 on. John $20: 30,31$ and John $21: 1-11$.

53. De Baptismo, Book IV. In this regard, see Ladner, Gerhart, The Idea of Reform, Harper and Row, New York, 1967, pp. 153-284.

54. Enn. on Psalm 133. See also Ladner, op. cit., pp. 350-366.

55. De Baptismo, Book VII.

56. Sermon 92 on John $14: 6$.

57. Tractate 32 on John 7:37-39. He continues:

We have therefore the Holy Spirit if we love the Church; but we love the Church if we stand firm in its union and charity. For the apostle himself, often he had said that diverse gifts were bestowed on diverse men, just as the offices of the several members, saith, "yet I show you a still more pre-eminent way"; and begins to speak of charity.

58. Enn. cn Psalm 40.

59. An extensive discussion occurs in Tractate 13 on John $3: 22-29$ on the common thread of charity running through charism and enabling virginity.

60. De Baptismo, Books III and IV. Tractate 5 on John $1: 33$.

61. Enn. on Psa1m 48. See a1so Tractate 12 on John 3:6-21.

62. Enn. on Psalm 41. However, the Redemption, as we11 as the Sacraments, is efficacious only for the elect. Enchiridion, Ch. 61.

63. Enn. on Psalm 147.

64. Sermon 21 on Matt. $12: 32$.

65. Sermon 26 on Matt. 14:25.

66. Tractate 50 on John 11:55-57, 12:1-11. Enn. on Psa1m 147. Augustine adds that, according to Psalm 11, these just stand as 1ights in the midst of a perverse generation.

67. Tractate 41 on John $8: 31-36$. The relationship between the Church and the concept of virginity is an interesting one. In Sermon 43 on Matt. 25:1, Augustine discusses, in the parable of the ten virgins, the relationship of virginity, that is, freedom from worldly cares, and the Church:

- . the whole Church which consists of virgins, and boys, and married men and married women, is by one name called a virgin. Whence prove we this? Hear the apostle saying, not to the religious women only but to the whole church together; "I have espoused you to one husband, that I may present you 
as a chaste virgin to Christ.". . Few have virginity in the body; in the heart all ought to have it.

See also, On Holy Virginity, in which the Church is described as a mother and virgin, comparing it with the Virgin Mary.

68. Sermon 28 on Matt. 17:1. See a1so, Concerning Faith of Things Not Seen, in which the Church is established as the fulfillment of prophecy and the 01d Covenant and can be seen as such.

69. Sermon 66 on Luke $24: 36$. In Enn. on Psalm 48, Augustine adds: "As we have heard, so we have seen" (ver, 7). Blessed Church! At one time thou has heard, at another time, thou hast seen. She heard in promises, seeth in performance: heard in Prophecy, seeth in the Gospel. For all things which are now fulfilled were before prophesized. . . .

70. Sermon I on Agreement of Matthew and Luke on the Generation of the Lord.

71. On True Religion 25, 47. For Augustine, the Church is the instrument of Christ's salvation in time. As is stated in the same work $(7,13)$ :

In following this religion our chief concern is with the prophetic history of the dispensation of divine providence in time--what God has done for the salvation of the human race, renewing and restoring it unto eternal life. . . .

72. Enn. on Psalm 10. Homily 3 on 1 John $2: 18-27$. The danger of heretics who "in holding false opinions regarding God, do injury to the faith itself," and schismatics who "in wicked separations break off from brotherly charity, although they may believe just what we believe," is discussed in on Faith and the Creed, in which Augustine excludes them from the Church by definition since the first does not love God and the second do not love their neighbors.

73. Homily 3 on 1 John $2: 18-27$.

74. Sermon 12 on Matt. $8: 8$ and I Cor. 8:10.

75. At another point, he writes (Ep. 133) to Marcellinus, a Roman official that those who were involved in a torture-murder of a priest not be killed but beaten with rods, adding: "Wherefrom it is generally necessary to use more vigor in making inquisition, so that when the crime is brought to light, there may be scope for displaying clemency." The subjective nature of the administration of such discipline has always been a troublesome question for the Church. By the same token, however, Augustine felt that crimes by Christians in enforcing compulsion without charity will be dealt with by God, Ep. 87; Enn. on Psalm 11. On one occasion (Ep, 100) he states that if capital punishment is used by the Romans, the Christians would not bring the Donatists to the attention of the authorities . 
76. On one occasion Augustine mentions that he refused the return of a Donatist daughter under the compulsion of her father, since she was not willing to return (Ep. 35). His letters reflect a constant willingness to debate the Donatists and speak of the difficulties of approaching them in getting past the fanatical Circumcilliones (Ep. 88). In a more polemical tone, he notes that the Donatists began the persecution (Ep. 51, 111).

77. Ep. 100. It should be pointed out that Augustine found the use of force to be a last resort (Ep. 34).

78. Ep. 93 and 111. He warns Crispinus, the Donatist Bishop of Calama, to fear the power of the civil authority less than that of God (Ep. 66).

79. Ep, 93. This letter marks the turn from persuasion to compulsion for Augustion, who now corrects his former opinion, stating that one must be taught by punishment if necessary, to prefer scripture to men. Fear commences re-examination and cures sluggishness, custom and temporization.

80. De Baptismo, Book IV, V.

81. Tractate 50 on John 11:55-57 and 12:1-11. See also, Tractate 124 on John 21:19-25.

82. De Baptismo, Books III and IV.

83. Enn. on Psalm 84. In Tractate 6 on John 1:32-33, Augustine confirms his thoughts on exclusivity within the Church: "There are the bad and good in the Catholic Church, but with them [the Donatists] the bad only." 


\section{CHAPTER II: HANS KUNG}

\section{A. Introduction}

As with Augustine, the works of Fr, Hans Kung are a response to a particular historical situation. Kung participated in the second Vatican Council, aided in the formulation of the documents which resulted therefrom and applauded from the beginning, the process of aggriornmento within the Church. This response is consistent with his belief that the Church must respond to the modern world in accordance with the spirit, rather than through adherence to a medieval philosophy, a baroque tradition and an ossified bureaucracy. Fr. Kung has studied at the Gerinan College and Gregorian University at Rome, the Institut Catholique and the Sorbonne in Paris, and is Director of the Institute of Ecumenical Studies, Dean of the Theological faculty, and Professor of Dogmatic and Ecumenica1 Theology at the University of Tubingen, Germany. 'Three of. his works will receive particular attention in this study of his ecclesi0logy: Structures of the Church $(1964)^{1}$ dealing with the relationships of laity and office; The Church $(1967)^{2}$ a treatise on the nature of the covenant-people, and Infallible: An Inquiry $(1971)^{3}$, a response to the Papal Encyclical, Humanae Vitae, elaborating on themes set forth in the two earlier works, with special emphasis on the teaching authority of the Church.

Kung first attracted attention in 1957, upon the publication of his doctoral dissertation, entitled Justification, which held that the concepts of Justification, as apprehended by the early reformers and 
Kar1 Barth, and that of Redemption as held by Catholic theologians, were in "fundamental agreement." Even more surprising was the inclusion of a letter from Barth to his countryman Kung, acknowledging the similarity and expressing hopes for a greater unity. As will be seen, Kung is greatly influenced by the reformers, early and modern, especially Barth.

During the Second Vatican Council, Kung was especially distinguished in his position as an officially invited theologian and official Theological Advisor to that body, reflecting the brilliance which made him a ful1 professor at Tubinger at age 32 . From that vantage point, he became a writer and lecturer as an authority on the Council and the Church. In 1963, he wrote The Council in Action, calling for internationalization and curtailment of the Curia, recognition of and greater authority to local councils of bishops. In a trip to the United States in that year, he attracted unprecedented crowds on his lecture tour and his reception among lay and religious alike was enthusiastic, especially in his constant call for freedom in the Church in the abolition of the Index, the Holy Office and other instrumentalities of "unfreedom" which are inconsistent with the Spirit. At the same time, he denied the scope of the teaching authority of the Church beyond scriptural limits and Papal jurisdictional power beyond that necessary for the ministry of that office, seeking to deduce the Papacy from the Church. He also created consternation in conservative Catholic circles by his statements to the effect that different Christian denominations merely expressed the same faith in different ways. In 1968, Kung came again to the United States to teach the theology of justification and the sacraments at the Protestant Union Theological Seminary in New York and voiced his hope that laymen would 
choose their own priests and the Pope in the near future. His work on the Council was well known through the production of The Council, Reform and Reunion (1963) but by this time his advocacy of a decentralized episcopacy, liturgical semi-autonomy, and other positions were well known and widely discussed.

The publication of the three works under consideration, especially the latest work, has caused much discussion as to the nature of the Church. The first work encouraged the work of the layman and theologian in the work of reform in the Church. The second work analyzed the nature of the institution and made suggestions for its reform. The third work is a short and somewhat hastily written polemic against the proposition of papal infallibility or doctrinal freedom from exror. His examination of the nature of the Church has been, to say the least, controversial, and possibly subject to sanctions by the Vatican. Nevertheless, his ecclesiology has been greatly influential both within and ouside the modern Church.

A11 of the works of Kung are fully documented and obviously the product of extensive research and study. However, the author is somewhat less than a dispassionate observer; indeed, he is a trenchant advocate for those reforms he feels to be needed within the Church. It is in this light that his positions should be examined.

Perhaps it would be most informative for the reader to consider Kung's idea of what the Church is not: it is not a heavenly body, but a mixture of good and evil men coexisting; it is not the body of elect but the fellowship of believers and unbelievers, all sinful and needing grace; it is not an institution worthy of belief in itself but only 
insofar as the Holy Spirit dwells within it; it does not give faith, but requires faith for membership and, similarly, is a balance between overemphasis on the believing individual alone and that of overemphasis on the community; it is not the last bastion of a western culture or an established, tradition-oriented pressure group, but the People of God, the Mystical Body existing as part of a divine plan for salvation which encompasses Creation and Redemption. ${ }^{4}$ This negatively-oriented beginning emphasizes the whole tenor of Kung's work -- the need for a return to Scripture in the concept of the Church in lieu of a mere historical approach. As sha11 be seen, this return cannot be accomplished alone by the individual believer, but requires a radical transformation, through love, of all believers acting in communion. Similarly, one should not lose himself in the divinely-oriented mission of the Church to the extent that its essential humanity is forgotten. Bearing in mind the nature of Kung's response, let us examine his ecclesiology.

B. The Names of the Church

Kung, unlike Augustine, was not a trained rhetorician but a theologian and student of Scripture; hence, his symbolic terminology with reference to the church is less extensive than that of the Bishop of Hippo. Yet the significance of this terminology is essential for an understanding of his concept of the Church.

The first concept used is that of "People of God." The Apostles understood themselves to be those who proclaimed fulfillment of the Mosaic Covenant, but, until they began their missions to the Gentiles, worked exclusively among the Jews, so that it was not until about $60 \mathrm{~A}, \mathrm{n}$. 
that they took on a separate identity and separate practices including the use of baptism as an initiatory rite and sign of purification, a community prayer and meal, their own leaders, a fellowship of love (koinonia), ${ }^{5}$ and an identity as "the true Israel." 6 This latest title, "Israe1," meaning "God reigns," eschatologically implies membership in both a nation or people as well as a religion and was used by the early Church in Acts $1: 6$ and $28: 21$ and Romans $9-11,7$ to signify the New Coven-. ant. The term "People of God" is used in Tit. 2:14, Rev. 18:4 and

1 Peter 2:9 to denote a spiritual relation with God, now open to a11 people:

The concept of the people of God is at the heart of Judaism. Fundamentally the whole faith of Judaism can be summed up in the single phrase: Yahweh is the God of Israel and Israel is the people of Yahweh. . . . And yet Israel's answer by no means always corresponds to the acts of God. The history of Israel is a story of repeated failures and betrayals, backslidings and loss of faith: a story of sin. Israel found itself more and more in a crisis, which was also a religious and political crisis and culminated in the destruction of the state, an event which was interpreted as a judgment and punishment for the sins of the people. It was the prophets who continually announced God's judgment and rejection to his faithless people and who preached God's mercy and his renewed election of them to a defeated and demoralized Israel. 8

Similarly, the people of God or the Church, as the Jews of the Old Testament, also suffer from many human maladies, but are attended by God's grace. Among the people of God there is no distinction between laity and clerics; all are sinners and in need of grace which comes through the community, rather than directly from God. ${ }^{9}$ The rite of Baptism initiates the individual into the community of God with a sign of grace and vocation which must be continually ratified through life (Rom. 9:6-13). ${ }^{10}$ Yet . membership in the community is helpful only to those who have grace, though all in the Church are called by God. In distinguishing "Israel 
of the flesh" from "Israel of the promise" (cf. Rom. 9:8-13), Kung

states:

. . Here God's sovereign freedom and inexplicable grace is at work, unfathomable, indeed a stumbling-block to man (cf. Rom. $9: 14-29)$. It is true that the guilt of man is presupposed here, indeed it is explicitly affirmed by Paul; but it is included within God's sovereign act. In freedom God chooses Isaac, not Ishmae1, Jacob, not Esau, Moses, not Pharoah. Man cannot quarrel with God about this. But Paul is not here concerned with the election or rejection, the salvation or damnation of individuals, as was mistakenly understood from Augustine through the Middle Ages to Luther and Calvin. In his historical and theological perspective here he is concerned with the election of a community as such, with the election of the people of God, Israel. God is sovereign even with regard to Israel's prerogatives. God's plan of salvation includes free choice, even though His promises are offered to the whole nation. He freely chooses and rejects, without in the least abandoning His purpose of grace and love, His aim to lead Israel as a whole to salvation. . . 11

The test of membership in the people of God, open otherwise to Jew or Gentile, is faith. ${ }^{12}$ on this people, God will show His mercy.

Another name used for the Church by Kung is "pilgrim," denoting "one who presses forward amid persecutions of the world and the consolation of God" (taken from Augustine). ${ }^{13}$ The work of the Church is long, her immediate resources are human and limited; she is aware of the impossibility of her task without God.

Finally, another emphasis of Kung's ecclesiology is that of the Church as those called by God to His banquet through His grace -- hence the name "ecclesia" or "the called," which term is used in Scripture to refer to individual congregations as well as the whole universal Church; the call to individual Christians is given through the Church by the Holy Spirit. ${ }^{14}$

In summary, then, the Church is the people of God, called to salvation by Him, and on earth, progressing to that end with His grace. 


\section{Ministry and Charism}

Kung's concept of the Church is rooted in the relationship of ministry and charism. As has been discussed with reference to Augustine, "Charism" (see, for example, I Peter 4:10) is a gift from God to each of His people. For some, it may be a give for administration, for others, prophecy, for still others, the gift of tongues. These are to be used for the good of the Church and each Christian must give freely of himself for God. ${ }^{15}$

Kung takes the position that there is no hierarchical order within the Church; instead, one looks to the ministry (the use of a charism) of the subject and its place in the order of the Church. Indeed, it is the ordering of charisms which is one of the chief duties of the Church. Yet in Scripture there is no ecclesiastical hierarchy nor ruler-ruled relation; instead, the word "diakonia" or "service" is used. ${ }^{16}$ The Apostles, as witnesses to Christ, have a unique ministry which cannot be succeeded in the same way, but other public charisms -. teaching, preach ing, prophesizing, etc., as well as leadership and administration are bound together in a hierarchical order (Rom. 12:4-8; I Thess. 5:12), though exact functions are not set forth by Scripture, which also gives no indication of "monarchical" rule or succession by appointment from other authorities among the early Christian commities. ${ }^{17}$ Indeed the officers mentioned, bishop ("episkopos" or "overseer") and deacon ("diakonia" or "helper" -- priest or "presbyter" as mentioned only in the Pastoral Epistles, whose Pauline authorship is questioned) are vague and their charism is far behind Apostles, prophets and teachers in Paul's list of charisms (I Cor. 12:29) and Kung finds no evidence to place 
Pauline communities apart from other early Christian communities. ${ }^{18}$ Though the early Jewish-Christian communities appointed elders (Acts $11: 30 ; 15: 2,4,6,22 \mathrm{ff} ; 16: 4,21: 18)$, Kung does not believe that Luke is correct in stating that Paul and Barnabas appointed elders in every church (Acts 14:23; 20:14-35), finding rather some autonomy in the early Christian communities, and noted that Paul does not look to ordination for the authority of commissioning elders or presbyters (the distinction is often not clear), although the Pastoral Epistles (for example $1 \mathrm{Tim}$. $4: 14 ; 5: 22$ ) indicate otherwise. ${ }^{19}$ Therefore, Kung finds a spjit within the New Testament in which the points concerning a monarchical Church, ordination and a priest-class have been emphasized within the Church, but the conflicting points have been ignored or omitted. Further, he finds that the duties of bishops and priests are similar in the early Church (Acts 20:17, 28 and Titus 1:7), though a monarchical structure is intimated in Titus $1: 5-8$ (which speaks of one bishop and several presbyters) and presumably progresses to the diocesan and papal structures through history. 20

Through a Scriptural and historical treatment, Kung then moves towards the Constitution of the Church, adopted by Vatican II, which he feels necessarily differs from the Tridentine structure by the import of clianged circumstances, ${ }^{21} i . e$. the lessening of the threat of the Reformation. Yet, there is support for a hierarchical (or, to use the pejorative, "monarchical") structure within the Church from the Pastoral Epistles mentioned above, the texts regarding the primacy of Peter, tradition and the need for a corporate decision-making process. None of these is denied by Kung, but they are, as a reaction to overemphasis on structure in the Church, perhaps underemphasized in his treatment of 
ministry. To be an ecclesiological relativist, finding the structure as a differing response to differing historical situations may go too far in ignoring the biblical essence of the structure.

The treatment of ministry is similar to charism. The Church attempts to coordinate ministry and charism, which is a primary responsibility in continuing its Apostolic (as well as teaching, prophesizing, administration, etc.) ministries in succession. 22 While some of these ministries are transmitted by ordination (or laying on of hands), all believers are priests as to certain functions as preaching, and sometimes baptism and penance, while other ministries as the pastoral office come from a special commission:

- But pastoral ministries have a pre-existing authority on the basis of the special commission with which they appear before the community. The pastor is therefore from the first a special person in the community, since he is authorized as one with special powers to exercise a special ministry in the public iife of the community. He has the power to found and govern committees, to call together, unite and build up the community; he has power to preach the word in the public assembly and to carry it out into the world as a missionary; he has power to lead public assemblies, to baptize and celebrate the Lord's Supper, to bind and to loose and commission other like himself. 23

It is in this way that the Church continues, though individuals are lost to her in time. The question of succession to the pastoral charism other than by ordination is left open, though the laity, according to Kung, possesses a larger role than once thought, through the priesthood of all believers and administration of sacraments other than Baptism. As will be seen later herein, the Pope also holds a ministry, but this is primarily a ministry of service, rather than of rule through holding a special position within the Church. ${ }^{24}$ 


\section{Representation within the Church}

One of the characteristics of the Church discussed above is its position as the community of those called by God to hear and follow His Word. Those who hear are also constantly called to reform in the face of varying fact-situations, as the Church responds to different stimuli (compare, for example, Nicea to Trent). It becomes necessary for the Church to come together to respond to an internal or external problem as an institution. Since it is impractical for all the Church to be involved in such discussions and decisions, representatives of the whole Church gather together in council for that purpose. The representation at such gatherings is virtual, rather than actual, but the gathering itself is a representation of the whole Church.

In discussing Vatican II in Structures of the Church, Kung develops this theory of representation. By analogy, the Word of the 01d.Covenant demonstrates a reduction of representation: a11 things in creation are represented by man which, in turn, is represented by Israel, which is represented by the two surviving tribes of Judah, and, 1astly, the whole 01d Covenant devolves in its representative, Christ. For the New Covenant, the representation expands -- Christ represents the Judaic Church, which expands to all men to call them to salvation. 25

The problems of the Medieval Church, according to Kung, often resulted by the politically motivated actions of the Papacy which was not correctly representing the Church, and, except for the Council of Constance which reacted to an emergency situation, the Great Schism, Councils, and counciliarism was an attempt to respond to a need for representation in the Church and was also one of the bases for the Iutheran 
formulation of the concept of priesthood of all believers as an attempt to effect real representation. ${ }^{26}$ Kung's point is that representation cannot, as with Vatican I, be confined to clerics. It can, should and must include the laity. 27

Representation in the local Church comes from the pastoral charism and ministry, which comes from God, and not from communal choice. A11 pastors have the duty of credible (i.e. witnessing the Word) representation of the Church. ${ }^{28}$ The local pastor therefore has the duty to preach and act the Word among his people in the way in which Christ would. His immediate superiors have the same duty, though acted upon in different circumstances.

Finally, the Papacy is a representative office born out of its primacy of ministry. But Kung finds medieval titles, absolutist methods and baroque expressions make the Pope less credible as a "prime minister" of the Church to non-Roman Catholics. ${ }^{29}$ In fulfilling his office as "servant of, the servants of God," the Pope must seek to adhere himself and encourage in others adherence to Scripture for effective witness and responsible ministry.

\section{E. The Nature of the Church}

Kung notes that the word "Church" appears only twice in the Gospels (Matt. 16:18, 18:17), whereas the words "Kingdom of God" ("Basilea") appear approximately 100 times. 30 The latter term is apocalyptic in nature and membership in the Kingdom, according to Kung, is dependent upon the radical choice of man for God affected by grace in every aspect of life, requiring a constantly inward-looking disposition which must be in accord with Scripture. ${ }^{31}$ The apocalyptic proximity of 
Karl Barth, and that of Redemption as held by Catholic theologians, were in "fundamental agreement." Even more surprising was the inclusion of a letter from Barth to his countryman Kung, acknowledging the similarity and expressing hopes for a greater unity. As will be seen, Kung is greatly influenced by the reformers, early and modern, especially Barth. During the Second Vatican Council, Kung was especially distinguished in his position as an officially invited theologian and Official Theological Advisor to that body, reflecting the brilliance which made him a ful1 professor at Tubinger at age 32 . From that vantage point, he became a writer and lecturer as an authority on the Council and the Church. In 1963, he wrote The Council in Action, calling for internationalization and curtailment of the Curia, recognition of and greater authority to local councils of bishops. In a trip to the United States in that year, he attracted unprecedented crowds on his lecture tour and his reception among lay and religious alike was enthusiastic, especially in his constant call for freedom in the Church in the abolition of the Index, the Holy office and other instrumentalities of "unfreedom" which are inconsistent with the Spirit. At the same time, he denied the scope of the teaching authority of the Church beyond scriptural limits and Papal jurisdictional power beyond that necessary for the ministry of that office, seeking to deduce the Papacy from the Church. He also created consternation in conservative Catholic circles by his statements to the effect that different Christian denominations merely expressed the same faith in different ways. In 1968 , Kung came again to the United States to teach the theology of justification and the sacraments at the Protestant Union Theological Seminary in New York and voiced his hope that laymen would 
choose their own priests and the Pope in the near future. His work on the Council was we1l known through the production of The Council, Reform and Reunion (1963) but by this time his advocacy of a decentralized episcopacy, liturgical semi-autonomy, and other positions were well known and widely discussed.

The publication of the three works under consideration, especially the latest work, has caused much discussion as to the nature of the Church. The first work encouraged the work of the layman and theologian in the work of reform in the Church. The second work analyzed the nature of the institution and made suggestions for its reform. The third work is a short and somewhat hastily written polemic against the proposition of papal infallibility or doctrinal freedom from error. His examination of the nature of the Church has been, to say the least, controversial, and possibly subject to sanctions by the Vatican. Nevertheless, his ecclesiology has been greatly influential both within and ouside the modern Church.

A11 of the works of Kung are fully documented and obviously the product of extensive research and study. However, the author is somewhat less than a dispassionate observer; indeed, he is a trenchant advocate for those reforms he feels to be needed within the Church. It is in this light that his positions should be examined.

Perhaps it would be most informative for the reader to consider Kung's idea of what the Church is not: it is not a heavenly body, but a mixture of good and evil men coexisting; it is not the body of elect but the fellowship of believers and unbelievers, all sinful and needing grace; it is not an institution worthy of belief in itself but only 
insofar as the Holy Spirit dwells within it; it does not give faith, but requires faith for membership and, similarly, is a balance between overemphasis on the believing individual alone and that of overemphasis on the community; it is not the last bastion of a western culture or an established, tradition-oriented pressure group, but the People of God, the Mystical Body existing as part of a divine plan for salvation which encompasses Creation and Redemption. ${ }^{4}$ This negatively-oriented beginning emphasizes the whole tenor of Kung's work -- the need for a return to Scripture in the concept of the Church in lieu of a mere historical approach. As shall be seen, this return cannot be accomplished alone by the individual believer, but requires a radical transformation, through love, of all believers acting in communion. Similarly, one should not lose himself in the divinely-oriented mission of the Church to the extent that its essential humanity is forgotten. Bearing in mind the nature of Kung's response, let us examine his ecclesiology.

\section{B. The Names of the Church}

Kung, unlike Augustine, was not a trained rhetorician but a theologian and student of Scripture; hence, his symbolic terminology with reference to the church is less extensive than that of the Bishop of Hippo. Yet the significance of this terminology is essential for an understanding of his concept of the Church.

The first concept used is that of "People of God." The Apostles understood themselves to be those who proclaimed fulfillment of the Mosaic Covenant, but, until they began their missions to the Gentiles, worked exclusively among the Jews, so that it was not until about 60 A.D. 
that they took on a separate identity and separate practices including the use of baptism as an initiatory rite and sign of purification, a community prayer and meal, their own leaders, a fellowship of love (koinonia), ${ }^{5}$ and an identity as "the true Israel." 6 This latest title, "Israel," meaning "God reigns," eschatologically implies membership in both a nation or people as well as a religion and was used by the early Church in Acts $1: 6$ and $28: 21$ and Romans $9-11,{ }^{7}$ to signify the New Coven-. ant. The term "People of God" is used in Tit. 2:14, Rev. 18:4 and 1 Peter $2: 9$ to denote a spiritual relation with God, now open to all people:

The concept of the people of God is at the heart of Judaism. Fundamentally the whole faith of Judaism can be summed up in the single phrase: Yahweh is the God of Israel and Israel is the people of Yahweh. . . . And yet Israel's answer by no means always corresponds to the acts of God. The history of Israel is a story of repeated failures and betrayals, backslidings and loss of faith: a story of sin. Israel found itself more and more in a crisis, which was also a religious and political crisis and culminated in the destruction of the state, an event which was interpreted as a judgment and punishment for the sins of the people. It was the prophets who continually announced God's judgment and rejection to his faithless people and who preached God's mercy and his renewed election of them to a defeated and demoralized Israel. 8

Similarly, the people of God or the Church, as the Jews of the O1d Testament, also suffer from many human maladies, but are attended by God's grace. Among the people of God there is no distinction between laity and clerics; all are sinners and in need of grace which comes through the community, rather than directly from God. ${ }^{9}$ The rite of Baptism initiates the individual into the community of God with a sign of grace and vocation which must be continually ratified through life (Rom. 9:6-13). ${ }^{10}$ Yet membership in the community is helpful only to those who have grace, though all in the Church are called by God. In distinguishing "Israel 
of the flesh" from "Israel of the promise" (cf. Rom. 9:8-13), Kung states:

- Here God's sovereign freedom and inexplicable grace is at work, unfathomable, indeed a stumbling-block to man (cf. Rom. 9:14-29). It is true that the guilt of man is presupposed here, indeed it is explicitly affirmed by Paul; but it is included within God's sovereign act. In freedom God chooses Isaac, not Ishmael, Jacob, not Esau, Moses, not Pharoah. Man cannot quarrel with God about this. But Paul is not here concerned with the election or rejection, the salvation or damnation of individuals, as was mistakenly understood from Augustine through the Middle Ages to Luther and Calvin. In his historical and theological perspective here he is concerned with the election of a community as such, with the election of the people of God, Israel. God is sovereign even with regard to Israel's prerogatives. God's plan of salvation includes free choice, even though His promises are offered to the whole nation. He freely chooses and rejects, without in the least abandoning His purpose of grace and love, His aim to lead Israel as a whole to salvation. . . 11

The test of membership in the people of God, open otherwise to Jew or Gentile, is faith. ${ }^{12}$ on this people, God will show His mercy.

Another name used for the Church by Kung is "pilgrim," denoting "one who presses forward amid persecutions of the world and the consolation of God" (taken from Augustine). ${ }^{13}$ The work of the Church is 1ong, her immediate resources are human and limited; she is aware of the impossibility of her task without God.

Finally, another emphasis of Kung's ecclesiology is that of the Church as those called by God to His banquet through His grace - hence the name "ecclesia" or "the called," which term is used in Scripture to refer to individual congregations as well as the whole universal Church; the call to individual Christians is given through the Church by the Holy Spirit. ${ }^{14}$

In sumnary, then, the Church is the people of God, called to salvation by Him, and on earth, progressing to that end with His grace. 


\section{Ministry and Charism}

Kung's concept of the Church is rooted in the relationship of ministry and charism. As has been discussed with reference to Augustine, "Charism" (see, for example, I Peter 4:10) is a gift from God to each of His people. For some, it may be a give for administration, for others, prophecy, for still others, the gift of tongues. These are to be used for the good of the Church and each Christian must give freely of himself for God. ${ }^{15}$

Kung takes the position that there is no hierarchical order within the Church; instead, one looks to the ministry (the use of a charism) of the subject and its place in the order of the Church. Indeed, it is the ordering of charjsis which is one of the chief duties of the Church. Yet in Scripture there is no ecclesiastical hierarchy nor ruler-ruled relation; instead, the word "diakonia" or "service" is used, ${ }^{16}$ The Apostles, as witnesses to Christ, have a unique ministry which cannot be succeeded in the same way, but other public charisns .. teaching, preaching, prophesizing, etc., as well as leadership and administration are bound together in a hierarchical order (Rom. 12:4-8; I Thess. 5:12), though exact functions are not set forth by Scripture, which also gives no indication of "monarchical" rule or succession by appointment from other authorities among the early Christian communities. ${ }^{17}$ Indeed the officers mentioned, bishop ("episkopos" or "overseer") and deacon ("diakonia" or "helper" -- priest or "presbyter" as mentioned only in the Pastoral Epistles. whose Pauline authorship is questioned) are vague and their charism is far behind Apostles, prophets and teachers in Paul's list of charisms ( $I$ Cor. 12:29) and Kung finds no evidence to place 
Pauline communities apart from other early Christian communities. ${ }^{18}$ Though the early Jewish-Christian communities appointed elders (Acts $11: 30 ; 15: 2,4,6,22 f f ; 16: 4,21: 18$ ), Kung does not believe that Luke is correct in stating that Paul and Barnabas appointed elders in every church (Acts $14: 23 ; 20: 14-35$ ), finding rather some autonomy in the early Christian communities, and noted that Paul does not look to ordination for the authority of conmissioning elders or presbyters (the distinction is often not clear), although the Pastoral Epistles (for example 1 Tim. $4: 14 ; 5: 22$ ) indicate otherwise. ${ }^{19}$ Therefore, Kung finds a split within the New Testament in which the points concerning a monarchical Church, ordination and a priest-class have been emphasized within the Church, but the conflicting points have been ignored or omitted. Further, he finds that the duties of bishops and priests are similar in the early Church (Acts 20:17, 28 and Titus 1:7), though a monarchical structure is intimated in Titus $1: 5-8$ (which speaks of one bishop and several presbyters) and presumably progresses to the diocesan and papal structures through history. 20

Through a Scriptural and historical treatment, Kung then moves towards the Constitution of the Church, adopted by Vatican II, which he feels necessarily differs from the Tridentine structure by the import of changed circumstances, ${ }^{21}$ i.e. the lessening of the threat of the Reformation, Yet, there is support for a hierarchical (or, to use the pejorative, "monarchical") structure within the Church from the Pastoral Epistles mentioned above, the texts regarding the primacy of Peter, tradition and the need for a corporate decision-making process. None of these is denied by kung, but they are, as a reaction to overemphasis on structure in the Church, perhaps underemphasized in his treatment of 
ministry. To be an ecclesiological relativist, finding the structure as a differing response to differing historical situations may go too far in ignoring the biblical essence of the structure.

The treatment of ministry is similar to charism. The Church attempts to coordinate ministry and charism, which is a primary responsibility in continuing its Apostolic (as well as teaching, prophesizing, administration, etc.) ministries in succession. ${ }^{22}$ While some of these ministries are transmitted by ordination (or laying on of hands), all believers are priests as to certain functions as preaching, and sometimes baptism and penance, while other ministries as the pastoral office come from a special commission:

- . But pastoral ministries have a pre-existing authority on the basis of the special commission with which they appear before the community. The pastor is therefore from the first a special person in the community, since he is authorized as one with special powers to exercise a special ministry in the public life of the community. He has the power to found and govern committees, to call together, unite and build up the community; he has power to preach the word in the public assembly and to carry it out into the world as a missionary; he has power to lead public assemblies, to baptize and celebrate the Lord's Supper, to bind and to loose and commission other like himself. 23

It is in this way that the Church continues, though individuals are lost to her in time. The question of succession to the pastoral charism other than by ordination is left open, though the laity, according to Kung, possesses a larger role than once thought, through the priesthood of all believers and administration of sacraments other than Baptism. As will be seen later herein, the Pope also holds a ministry, but this is primarily a ministry of service, rather than of rule through holding a special position within the Church. 24 


\section{Representation within the Church}

One of the characteristics of the Church discussed above is its position as the community of those called by God to hear and follow His Word. Those who hear are also constantly called to reform in the face of varying fact-situations, as the Church responds to different stimuli (compare, for example, Nicea to Trent). It becomes necessary for the Church to come together to respond to an internal or external problem as an institution. Since it is impractical for all the Church to be involved in such discussions and decisions, representatives of the whole Church gather together in council for that purpose. The representation at such gatherings is virtual, rather than actual, but the gathering itself is a representation of the whole Church.

In discussing Vatican II in Structures of the Church, Kung develops this theory of representation. By analogy, the Word of the 01d. Covenant demonstrates a reduction of representation: all things in creation are represented by man which, in turn, is represented by Israel, which is represented by the two surviving tribes of Judah, and, lastly, the whole old Covenant devolves in its representative, Christ. For the New Covenant, the representation expands -- Christ represents the Judaic Church, which expands to all men to call them to salvation. 25

The problems of the Medieval Church, according to Kung, often resulted by the politically motivated actions of the Papacy which was not correctly representing the Church, and, except for the Council of Constance which reacted to an emergency situation, the Great Schism, Councils, and counciliarism was an attempt to respond to a need for representation in the Church and was also one of the bases for the Iutheran 
formulation of the concept of priesthood of all believers as an attempt to effect real representation. 26 Kung's point is that representation cannot, as with Vatican $I$, be confined to clerics. It can, should and must include the laity. 27

Representation in the local Church comes from the pastoral charism and ministry, which comes from God, and not from communal choice. A11 pastors have the duty of credible (i.e. witnessing the Word) representation of the Church. ${ }^{28}$ The local pastor therefore has the duty to preach and act the Word among his people in the way in which Christ would. His immediate superiors have the same duty, though acted upon in different circumstances.

Finally, the Papacy is a representative office born out of its primacy of ministry. But Kung finds medieval titles, absolutist methods and baroque expressions make the Pope less credible as a "prime minister" of the Church to non-Roman Catholics. 29 In fulfilling his office as "servant of the servants of God," the Pope must seek to adhere himself and encourage in others adherence to Scripture for effective witness and responsible ministry.

\section{E. The Nature of the Church}

Kung notes that the word "Church" appears only twice in the Gospels (Matt. 16:18, 18:17), whereas the words "Kingdom of God" ("Basilea") appear approximately 100 times. 30 The latter term is apocalyptic in nature and membership in the Kingdom, according to Kung, is dependent upon the radical choice of man for God affected by grace in every aspect of life, requiring a constantly inward-looking disposition which must be in accord with Scripture. ${ }^{31}$ The apocalyptic proximity of 
this kingdom in the future is combined with the realization of the kingdom in one's life:

... God acts in the present and in the future; the one is dependent on the other, and hence faith and hope belong together in different perspectives of one and the same acceptance of God's gracious will in the present and the future. Because we believe in the present, we can, against aj.1.hope, hope for a future; and because we hope for a future we can, against any skandalon, believe in the present. 32

Baptism and the Eucharist represent the state of this kingdom: baptism, reminding man of his fall and the Eucharist of his coming union with God. ${ }^{33}$ The mission of this kingdom is to bring this word to all men and to administer these signs with the coming of the kingdom in mind. The celebration of the community meal and the rite of affirmation of faith marked the new community (Acts $2: 42-47$ ) which now officially referred to itself as "the people of God" or "ekklesia" (those called out). ${ }^{34}$ The use of "Church" in the New Testament has some varied forms: it may mean the process of congregating, the congregated community, and both the individual or universal Church; ${ }^{35}$ however, in every case, it retains the sense of a "called community." Kung stresses the apocalyptical nature of the Church moving towards its predetermined goal, "Parousia" or manifestation. ${ }^{36}$ While being aware of the real roots the institution has taken in the world, the progress to the kingdom of God continues: . . Ekklesia is a pilgrimage through the interim period of the last days, something provisional: basilia is the final glory at the end of all time, something definitive. Ekklesia embraces sinners and righteous, basilia is the kingdom of the righteous, of the saints. Ekklesia grows from below, can be organized, is the product of development and progress and dialectic, in short is definitely the work of man; basilia comes from above, is an unprepared action, an incalculable event, in short is definitely the work of God. . . .37

While on the pilgrimage of this life, the mission of the Church is to call human attention to the "already-not yet" manifested Kingdom of God. 
F. The Teaching of the Word

Kung's ecclesiology is heavily dependent on Scriptures which he holds superior to non-divine tradition and other history. It is necessary, therefore, to examine his thought as to how the Word is to be passed on to the faithful by the Church as a part of its mission.

Kung stresses the humanity of the Church and in its teaching office and its response to specific historical situations (such as the Schism with Orthodoxy, the medieval position on usury, Galileo, the rites controversy, secular papal power, the Index) to demonstrate that this office has erred, asserting that Humanae Vitae was merely the most recent example. ${ }^{38}$ According to Kung, Pope Paul was bound by his determination that the credibility of the teaching office, especially the encyclical Casti Conubii (1930) be preserved and could find no way around the work of Pius XI, but has no Scriptural basis for the conclusions of his predecessor. As to Scripture, Kung believes that the word is revealed within the Church, rather than privately, just as faith in the Church, upon recognition of the attributes of the Community of Christians, is demanded of the individual Christian. ${ }^{39}$ The limits of this demand pose a difficult problem for Kung in which his position has been less than completely consistent. The relationship between Papal, Counciliar and Episcopal-Papal infallibility to the ordinary magisterium of the Church in teaching the word is sufficiently close to bring the two into question and thereby arouse a new controversy.

Infallibility is the impossibility of falling into error. It is accorded to the Pope when sepcial circumstances since Vatican $1^{40}$ (based on Matt. 28:20; John 14:16ff; and Luke 10:16, and 1 Tim. $3: 15$ ), and to 
validly-called councils and bishops when teaching in accord with the Pope since Vatican II, ${ }^{41}$ The scope of this power is wide, extending to revealed teachings and facts closely connected therewith (theological conclusions, dogmatic facts, truth of natural reason and canonization of saints). ${ }^{42}$ The problems raised are extensive and deal not only with allegedly erroneous Papal decisions but those of councils themselves -what of a conflict between Pope and Council where the council is truly ecumenical (i.e. a representation of the universal Church) and the effect of councilar credibility when one council corrects another. ${ }^{43}$

The subject matter of infallibility is of concern to Kung to the same extent as the person or body which may proclaim doctrine. Kung finds the notion of infallibility too static and urges reconsideration of the thesis of the Tubingen School and Cardinal Newman on the idea of the development of doctrine in lieu of what he describes disdainfully as "textbook theology." 44

Similarly, the nature of infallibility should be discussed with reference to the basis of the doctrine so proclaimed, Kung contends that if the three Scriptural passages utilized by Vatican I as a basis for Papal infallibility are examined, they will demonstrate that promise is given to the entire Church and not merely to Peter. ${ }^{45}$ Using his concepts of charism and ministry, Kung contends further that the gift to the apostles of the spirit is not a guarantee of freedom from error, since there is no succession to the apostolic charism, and that there is no proof of the succession of this power to the Bishops. ${ }^{46}$ No indication is gives as to whether infallibility could be passed on as a part of the Papal ministry of service. 
According to Kung, the problem of infallibility is compounded by the Church through time. His objection is that the Church has used Tradition to interpret Scriptures and has used the teaching office especially in the Papacy to control both. The problem is stated thus:

- . The Catholic theologian will have to agree with the Evangelical when the latter protests against the assimiliation of the Church's truth to God's truth, with the result that the ambiguous historical reality of the Church is set up as an unequivocal sign of the credibility of Christian truth, faith is tied to the self-confident judgment of the Church ever in regard to the disciplinary questions of entering or leaving the Church, and a system of ecclesiastical dominion is set up over souls and over biblical interpretation. 47

This is not to say that Kung denies the role of Tradition in the Church; rather, he believes that Scripture is superior to the habit of centuries. Further, he asserts the truth of the promises of Christ to the Church that the Spirit of Truth will always dwe11 within it - - but adds that it cannot be denied that error also dwells within. ${ }^{48}$ Even Scripture is not unambiguous and, alone, is not an alternative, for, according to Kung, the theory of inspiration, as propounded by Augustine, which finds man to be a mere instrument of divine formulations which cannot be incorrect in any way, falls short of the mark; Scripture is not revelation, merely an attestation thereof in human terms. ${ }^{49}$ This attestation finds truth beyond mere verbal propositions:

Truth of Scripture means in the last resort truth beyond all true propositions, as the term is used in the old and New Testament; "truth" (emet, aletheia) means, over and above the truth of words and sentences, fidelity, constancy, reliability; the fidelity, that is, of the God of the Covenant to his Word and to his promise. There is not a single passage of Scripture that speaks of Scripture as not containing any error. . . .50

It is a linguistic basis that Kung finds the most fault with the teaching office and the doctrine of Infallibility. Propositions may be 
true and false at the same time, since they are human statements and open always to error. 51 Since inspiration is not direct, the human authors acting with divine assistance could formulate propositions which may be erroneously apprehended by the writer and reader. As a solution, Kung proposes that the term "infallibility" be replaced with the term "indefectability," a fundamental adherence of the Church to the truth despite error, which is consistent with the Scriptural promises of truth remaining within the Church, without the cumbersome assertion of a propositional inerrancy which:

1. Fails to capture the reality of the truth signified.

2. May lose its meaning in translation.

3. May be misunderstood as language evolves.

4. May be misunderstood as formulated.

5. Is prone to ideology or adherence to a particular school, such as Thomism. 52

Taking a leaf from the history of European philosophy, Kung finds the notion of propositional infallibility based on rationalist theory of truth, which he discards in favor of a more dynamic version in the tradition of Leibnitz, Kant and Hege1. 53 only God can propound absolute truth, which He does in non-linguistic terms, therefore, the believer must 10ok neither to the Church nor Scripture for truth but to God. 54 "Truth," then is taken to mean a pledge that if the Church adheres to the Word, it will share in God's truth despite its formulation within erroneous propositions.

Several points should be noted in the formulation of Kung's ecclesiology. The first of these relates to his view of history and its effect on the Church. While not adhering to a linear concept of history, Kung apparently takes the position that the Church responds to particular historical situations in such a manner as to make the institutional changes 
caused thereby to become irrelevant at some future date. It seems that the Church, in moving through history, gains practical knowledge and institutional methods in arriving at decisions and facing problems. While these institutional increments are sometimes unnecessary, many, if not most carry with them cogent (and often forgotten) reasons for their existence. If the present form of the episcopal or priestly office, the present structure of the institutional church or other items do not carry with them explicit Scriptural sanction, their existence remains based on those centuries of accumulated wisdom which, if not contrary to Scripture, is a continuing part of the manifestation of witness and the presence of the Spirit who will not desert the Church whether or not the Pope continues to wear the triple tiara. The promises accorded the church are more than a sufficient basis for the formulation of action by individual believers, if their informed consciences do not deny the same. Those who do so reject the community of believers through its representatives at their peril. Further, the need for institutional, as well as individual, reform is apparent in the Church but such reform as adopted by the representatives of the Church, and, as with any institutional change, is slow in enactment and should not be determined by history (which merely add increments to the essential nature of the Church) but by Scripture. If, as Kung states, the concept of the Church is historically conditioned, 55 the early Church differed from the present Church, or was unaware of its nature -- both alternatives deny the formulation of any concrete and lasting concept of the Church.

In addition to the historical problem, Kung's linguistic theory raises several problems. If Scripture be erroneous in its formulations, what standard can man utilize to justify his life? It is insufficient to 
state that the Church will remain fundamentally attached to the truth if that truth be incapable of definition. Rather, it seems that attempts at infallible verbal propositions, whether the ordinary or extraordinary magisterium be involved, are responses to particular situations and not an attempt to address themselves to all problems at one time. As new aspects of situations evolve, new responses must be studied. The alternative of Kung leaves the Church and its members without any concrete norms for action and abandons them to profound skepticism.

A critical aspect of Kung is his sympathy with the reformers and Karl Barth, the subject of an earlier work by Kung. Like Luther, Kung believes that the Church lacks constancy to truth (or, as he terms it, "credibility"); like Luther, Kung emphasizes the Prjesthood of all believers over designation of any priestly class; like Luther, he finds the episcopal office not to be essential; like Luther, there is a constant primacy of faith and little concern for works, even as a function of faith; like luther, he mentions only two Sacraments - Baptism and "the Lord's Supper": Like Luther, he adheres to Scripture without giving any real aid in its interpretation; and, like Luther, Kung predicates his position on the faith of the subject who can then be availed by grace and the presence of God in the Church, which is similar to the Lutherain view of the efficacy of the Sacraments to a man without faith, which came from the nominalist tradition.

Perliaps many of these problems are those of translation or emphasis. Yet the similarities are sufficiently disturbing for the problems to be raised. The history of Ecumenism seems hopeful to the extent that many problems can be explained (as Kung does on many occasions) without 
abandonment of one's position, a good use for a linguistic theory. Yet to state that truth can never be apprehended stifles a human need as strong as the religious need. 
FOOTNOTES: CHAPTER II

1. Kung, Hans, Structures of the Church, Thomas Ne1son and Sons, New York, 1964. (Hereinafter referred to as "Structures.")

2. Kung, Hans, The Church, Sheed and Ward, New York, 1967.

3. Kung, Hans, Infallible? An Inquiry, Doubleday and Company, Garden City, New York, 1971. (Hereinafter referred to as "Infallible.")

4. In "A Candid Preface to Infallible" (pp. 12-30), Kung finds renewal "halted" in Church and theology by the Curia and the use of encyclicals, decrees, etc. What Scriptural support or theological basis. Their use does not have the "desired" effect and encourages disrespect for the Church and continues the causes for schisms and the Reformation. Other complaints include retention of the inquisitional process (including the use of the Imprimatur which is merely "censorship" of one school of theology by another, to some works, including The (hurch), birth control, mixed marriages, indulgences, the proclamation of Mary as "Mother Ecclesiae," endorsement of Marian pilgrimage centers, and canonization. See also, Kung, Hans, Justification, Burns and Oates, London, 1957, p. 17.

5. The Church, pp. 28-39.

6. Ibid., pp. 108-113. In "Pie-in-the-Sky Theology," Commonweal, Vol. 88, p. 42, Danie1 Callahan criticizes the lack of a more concrete definition of the Church by Kung, finding it "frustrating" that the author talks at great length on the Church but never comes to terms with that body, leaving the definition open for future scholarship.

7. Ibid., p. 115. As with Augustine, Kung notes Paul's words which distinguish Israel of the flesh and Israel of the Spirit -- it is not membership in Israel alone which guarantees that one is one of the People of God.

8. Ibid., pp. 116, 118. See also Structures, p. 11.

9. Ibid., pp. 126-128. He continues at p. 128:

The Church begins, not with a pious individual, but with God. The pious individual cannot by himself achieve the transformation of isolated sinful man into the people of God. How could an atomized crowd of pious individuals be a home for the homeless and isolated men of today?

In Justification, p. 164, Kung finds every sin to be anti-social in character, estranging men from the people of God, which estrangement is not ended until he is reconciled through penance. 
10. Ibid., pp. 128-130.

11. Ibid., p. 143.

12. Ibid., p. 145. Kung notes Rom, $11: 26$, which states that "all Israel will be saved" which applies not to individuals but to the people who are saved. A11 men, he states from Rom. 11:32, are disobedient, so all men need His mercy.

13. Ibid, , p. 132.

14. Structures, pp. 11-14.

15. In The Church, at p. 393, Kung states:

-. Service to others is not a matter of self-righteous good works; it is derived from God and directed towards God -- each according to the call he has received, the charism given to him. (Cf. I Cor. $12: 11 ; \mathrm{cf}, 7$ ).

16. Ibid., p. 389.

17. Ibid., pp. 348-402. There is no Scriptural support for a "TheologIcal Ministry," though Kung advocates such a separate discipline.

18. Ibid., pp. 394-404. Neither were these charisms distinguished on a 1ay-clerical basis.

19. Ibid., pp. 405-406. An elder is given certain duties in I Tim. 5:17 and certain duties are attributed to a priest in $I$ Peter $5: 1-4$ and Acts $20: 28-35$.

20. Ibid., pp. 407-412.

21. Ibid., pp. 418-422.

22. Ibid., pp. 426-434.

23. Ibid., p. 440. The priest has no mediating function between Christ and man. Only Christ serves that function between man and God (I Tim, $2: 5$; Heb. $8: 6 ; 9: 15 ; 12: 22,24)$ though al1 men make sacrifices of praise to God through Christ, which sacrifices are, nevertheless, unable to duplicate that of Christ on the cross. Ibid., pp. 365-370. Kung asserts that there was no class of priests until the third century. Ibid., p. 387.

24. The Petrine ministry is a pastoral one over the Church in Collegiality with the remainder of the Bishops. Kung recognizes the special intimacy of Peter and Christ and his primacy over the Apostles but raises several important questions: Does primacy among the Apostles continue to be a primacy in the Church? Did such primacy die with Peter, who is not mentioned after Acts $15: 7$ and Gal. $2: 11$, nor is a successor named? Should the primacy continue with Rome? Kung concludes that the Petrine office is a primacy in ministry, held not 
on the basis of lineage, but on the basis of witness to the Gospel. Ibid., pp. 449-485. See also, Infallible, pp. 243-245.

25. Structures, pp. 18-19.

26. Ibid., pp. 71-74.

27. Ibid., pp. 93-97. Kung notes that. the Tubingen Schoo1, and Popes

Pius $X$, Pius XI and Pius XII all encouraged greater lay participation in the Church. Though now charged by Canon Law, councils originally neither had to be called or confirmed by the Papacy. Indeed, they were usually called and presided over by laymen. Structures, p. 4.

28. Ibid., pp. 213-216.

29. Ibid., pp. 226-227. See also The Church, p. 451.

30. The Church, p. 43 .

31. Ibid., p. 37. This "new man" aspect of renewal is in accord with Paul and Augustine.

32. Ibid., p. 69, see also p. 56. Kung stresses the need to "de-mythologize" eschatology in Revelation, just as much as protology in Genesis. What is important, he finds, is the kerygma of the coming reign of God.

33. Ibid., p. 65 .

34. Ibid., pp. 80-81. The word "ekklesia" in Acts can refer to the local church, the universal Church, a town or district. The use of that word in Acts refers to the Church in Jerusalem $(5: 11 ; 8: 1,3)$, the new Israel in the desert $(7: 38)$ and other churches $(9: 31)$.

35. Ibid, , pp. 84-85.

36. Ibid., p. 87. The multiple use of "reign of God" in the Gospels and scarce use in Acts and the Epistles is accounted for in that in the former, the reign was not yet accomplished, whereas in the latter it was and, at the same time, will not be complete until the last day. Ibid., p. 84 .

37. Ibid., p. 93. With the exception of the emphasis on numbers (i.e. the seven ages of man), Kung and Augustine are in basic agreement as to the relation of the Church and the Kingdom of God. pp. 90-91.

38. Infallible, pp. $31-32,39,50,51,52,85,86,106$. Kung finds that the conscience can be more binding on. one than the Encyclical, but also finds that this does not answer the problem relative to the authority of the teaching office. The problem with Humanae Vitae, according to Kung, is lack of any substantial Scriptural basis: the 
Encyclical refers to Scripture 16 times (never meaningfully, he contends), to the "Gospel" twice, to Vatican II 13 times, to the Magisterium 25 times and to Papal writings 40 times. p. 48.

39. Justification, p. 80 .

40. For the language of Vatican I on this subject, see Infallible, pp. 95-100. This position was affirmed in Chapter III of the Constitution of the Church in Vatican II. Ibid., pp. 69, 71. Kung fears that the Pope may take a position which forces the remainder of the Church into heterodoxy. Ibid., p. 104.

41. Infallible, p. 72. Kung contends that the concept of teaching office, or Magisterium, originated with Vatican I and is without any Scriptural basis. Neither the Bishops nor the Pope, despite their charisms, can teach any doctrine which is not in accord with reason and Scripture; in this task, theologians are necessary. Ibid., pp, 222-233. The problem with this position is that each man judges as to concordance with Scripture and reason.

42. Ibid., p. 69. The inability to err is de jure, and not merely de facto. Ibid., p. 140.

43. Ibid., pp. 203-206. Augustine stated that councils could correct (emendare) one another and were judged solely by Scripture.

44. Ibid., p. 150. While proclaiming new (and unscriptural) Marian doctrine, Kung sees some change in the rejection of extreme antimodernism by Vatican II's declaration that there is no new Revelation. Such will force reconsideration of present Revelation. pp. 75-79. In Justification, p. 105, Kung states that such "textbook theology" or other "correctable" items do not warrant separation of Christians.

45. Ibid., pp. 75, 109.

46. Ibid., pp. $82-84$.

47: Ibid., pp. 76, 141-142. The problem becomes even deeper when the historical circuinstances of Vatican I (reaction, dissolution of the Papal States and the indignation of Pius IX) are taken into account. Kung asks whether infallibility wasn't a mistake forced upon that Council. Ibid., pp. 84-93.

48. Ibid., p. 173 .

49. Ibid., pp. 210-217. Kung finds some credence for his theory in Vatican II which de-emphasized verbal inspiration and substituted for it the notion of its fundamental truth.

50. Ibid., pp. 220-221. 
51. Ibid., pp. 170-172.

52. Ibid., pp. 157-161, 175, 219. The term "indefectability" is one formulated by Yves Congar.

53. Ibid, $\mathrm{pp}, 165-167$.

54. Ibid, , pp, 160, 293 .

55. The Church, p. 5 . 
CHAPTER III

\section{A COMPARISON OF SELECTED SUBJECTS}

In order to compare the two writers fully, it is necessary to determine common points upon which they have expounded. The following areas represent such common subject matter, of which it can be fairly stated that the two have made observations which may be of interest to students of ecclesiology,

\section{A. Authority}

The Augustinian position as to ecclesiastical authority is governed by the law of love and the authority of Scripture. These two considerations are superior to pronouncements of individual bishops or those bishops gathered together in ecumenical councils, since bishops or councils may correct ("emendare") one another on the authority of Scripture:

. . when, by some actual experiment, things are brought to light which were before concealed, and that is known which is previously lay hid, and this without any whirlwind or sacreligious pride, without any puffing of the neck through arrogance, without any strife or envious hatred, simply with holy humility, catholic peace and Christian Charity.1

Augustine appealed to the authority of Scripture during the Donatist controversy, but his writings emphasize the need for charity and unity above al1. He exhorted the Donatists to reestablish communion with the churches throughout the world, pointing especially to St. Cyprian, the martyr-bishop of Carthage, who acceeded to a former African council which allowed the practice of re-baptism, but which was overruled by a later council to which Augustine asks submission, finding that, to a 
point and for the sake of peace, the church may allow for differing opinions to be debated in unity, but, on the discovery of truth, the Church must become united in doctrine. ${ }^{2}$ Augustine extols Cyprian's love which "covers a multitude of sins" and commends to all Cyprian's ruling in the rebaptism controversy:

It remains that we severally declare our opinion on this same subject, judging no one, nor depriving any one of the right of communion if he differs from us. . . For not one of us setteth himself up as a bishop of bishops, or by tyrannical terror forces his colleagues to a necessity of obeying. . . Inasmuch as any bishop, in the free use of his liberty and power, has the right of forming his own judgment, and can no more be judged by another than he can himself judge another. . . But all must avoid the judgment of Our Lord Jesus Christ, who alone has the power of setting us in the government of His Church and of judging our acts therein, 3

While some Donatists act from erroneous consciences and thus sin less gravely than others, the peace and unity of the Church is broken nevertheless by their contumacy which is contraxy to Scripture, which states that even if one has faith which moves mountains and gives his body to be burned, if he has not love, all this is of no avail. To Augustine, this disregard of the law of love is the real indictment of the Donatists, 4

The frequency of scriptural citations in his work indicates that Augustine was familiar with, and relied heavily upon, that body of authority. Indeed, his change of position from that he1d by Cyprian is based upon the more recent interpretation by a council in the rebaptism controversy and the scriptural dictum "compel them to come in." Apparently scriptural interpretation and the authority of the council provided a sufficient basis upon which to conpel the Donatists to end their separation. $^{5}$ 
Kung, on the other hand, is critical of certain councils, especially Vatican I. He too is cognizant of scripture and sacred citations appear throughout his work. Indeed, his gravest opposition to Casti Conubii and Humanae Vitae is the lack of Scriptural support for the papal positions therein. ${ }^{6}$ His most difficult arguments in consideration of infallibility are those centering around the scriptural promises of the presence of truth in the Church and their reconciliation with the errors ascribed to the teaching office. ${ }^{7}$ He concurs with Luther and Calvin that councils can err (though he understands the term in conjunction with his theory of indefectability) if they do not act in accord with scripture. 8 The proposition of Papal Infallibility has been seriously questioned by Kung, who would limit the concept in any case to a pastoral exercise and even then would carefully circumscribe its limits. ${ }^{9}$ In the case of bishops, councils or popes, Kung would examine the teachings of each compared to Scripture, the sola auctoritas. Additional comments will be noted in the position vis a vis the authority of Scripture taken by Kung.

\section{B. The Papacy}

The institution of the Papacy was not fully developed in the time of Augustine. The Pope was the Bishop of Rome and the successor of Peter, but there were few indications of the position and power that was later to accrue to that office. However, this is not to state that the Petrine office had no special position among the local churches of Africa and throughout the empire. A letter ${ }^{10}$ by Augustine to Caelestine, Bishop of Rome (413) begins with a "Your Holiness" and speaks to a problem which occurred when Augustine consecrated a local monk as bishop of ancther town. The monk became a scandal to his office and had to be 
removed. Fearing that Caelestine may believe the bad reports of his enemies, Augustine explains his conduct and confesses his bad judgment, noting that prior cases of this nature are judged by the "Apostolic See." There js, thus, an indication of a primacy of jurisdiction in the Roman Bishop at even this early date. On another occasion, Augustine speaks extensively on the nature of the Petrine office as based on the position of Peter:

- . So does the Church act in blessed hope through this troubled life, and this Church, symbolized in its generality, was personified in the Apostle Peter, on account of the primacy of his apostleship. . . . he represented the universal church, which, in this world is shaken by diverse temptations, and comes upon it like torrents of rain, floods and tempests, and falleth not, because it is founded upon a rock (petra), from which Peter received his name. 11

On another occasion, Augustine notes the communion of the African Catholics, unlike the Donatists, with the Roman Church, in which the supremacy of an Apostolic chain has always flourished. ${ }^{12}$ To summarize, though the centralization of the Church and position of the Papacy had not taken definite form, there are indications in the Augustinian corpus of a primacy of jurisdiction over the entire Church by the See of Rome which was recognized by Augustine and, presumably, the Empire.

Kung prefers to view the Papacy in the sense of a Petrine office, based on charism. The duties of this office are set forth thus: - . In the ecumenical council by divine convocation which is the Church, the Petrine office has the special task of representing and guaranteeing the unity of the Church in the service of charity, of strengthening the faith, and of pastoral care. 13

Kung is strongly against the retention of Papal pomp and grandeur which might lessen the effectiveness of his pastoral work and leadership in the spreading of the gospel. ${ }^{14}$ The pastoral primacy of the Petrine 
office, according to Kung, reached its limits of Vatican I, Canon 218, which documents state:

81. The Roman Pontiff, the successor to the Primacy of St. Peter, not only has the primacy of honor but the supreme and full juridical power over the universal Church in regard to faith and morals as well as in what pertains to discipline and government of the Church which is spread throughout the whole world.

\$2. This power is truly episcopal power, ordinary and immediate, over each and every individual church as well as over each and every shepherd and believer and independent of any human authority.

In order to fulfill this prime ministry, Kung believes that the office ought less to be inclined to juridical matters and should find its fullest realization in "diakonia" or service (Rom. 12:7-8).$^{15}$ This position is consistent with his apprehension of the nature of the charism of administration and pastoral care. The need for leadership of the Church, he concludes, is not contrary to Scripture (and he indicates Melancthon and Barth would have little trouble accepting the primacy of the Roman See without its full juridical implications) but must be based on witness, consistent with the Apostolic charism of the Church, and not merely on lineage. ${ }^{16}$ Further, the criticism of Kung to the Papal claim to infallibility has been discussed, but the implications of this linguistic agnosticism are not altogether clear. If there be no propositions of faith which can be communicated, save for the feeling that there exists a kerygma, the nature of which is unclear, the function of the Prime Pastor is similarly unclear.

Considered even in its pastoral aspects, however, Kung finds that the Petrine office is not unlimited. It may do no act which is contrary to divine law and it cannot interfere with the institution of the Episcopate. 17 This last limitation is formulated in the "principle 
of subsidiarity," by which the individual bishop shall not be negated in his daily decisions by the Papacy as primate of all bishops. ${ }^{18}$ As a general principle, he advises the Papacy to give "as much freedom as possible, as much restraint as necessary."19 In case of a conflict between a Pope and the Church, the Pope may be (and has been, historically) judged if he either leaves the faith or accedes to his office in an illegitimate manner - - this and the leaving of a Pope from office (by reason of death, resignation, mental illness, heresy or schism) must be judged, if necessary, by the whole Church and its representatives gathered in Council. 20 The precedent of the fifteeth century council of Constance, the effect of which is disputed, is seen by Kung to demonstrate the superiority of jurisdiction of a Council over that of the Pope. $^{21}$ Further, he believes that full jurisdictional power, symbolized by the power to bind and loose, is not given only to Peter and his Roman successors, but to the entire Church, using Augustine as one of the authorities for this proposition. ${ }^{22}$ Yet if the Petrine office is responsible for the administration of the Church, and no council is in session, that office acts as the representative of the entire Church and must, in the exercise of its pastoral ministry, decide matters of faith, and therefore holds those keys. Similarly, if the formulation of indefectability proposed by Kung were adopted, there would be nothing to bind and loose, but a mere subjectivist approach to faith. Such a concept of the Petrine office posits the Papacy a titular head presiding over chaos. 


\section{The Marks of the Church}

The final comparison under consideration concerns the signs or marks of the Church, distinguishing it from other bodies, including those which claim to follow Christ. Augustine, responding to the Donatist heresy, is more exclusion-minded than Kung, the ecumenist. Yet in a study of comparison, the particular point of the signs of the Church is of great importance.

1. The Church is One. Augustine never failed to stress the necessity of a unity in chairty as a requisite of the Church:

. . Charity of Spirit, respect for our fraternity, the bond of faith, the harmony of the priesthood, are by us maintained with patience and gentleness. ${ }^{23}$

While men in the Church may be disruptive of unity, their presence is no grounds for individual churches to dissolve their bonds with the remainder of the Church. ${ }^{24}$ This desire for unity, and not the rebaptism controversy, is the primary source of his disagreement with the Donatists:

. . Be assured, therefore, that we detest nothing in the Donatist clergy but that which renders them schismatics and heretics, namely their dissent from the unity and truth of the Catholic Church, in their not remaining in peace with the people of God, which is spread abroad throughout the world, and in their refusing to recognize the Baptism of Christ in those who have received it. 25

His later anti-Donatist works reflect Augustine's position that God will judge harshly those who break the unity of His Body. ${ }^{26}$ At another point, he uses the twelve Apostles as a symbol of unity and disunity:

... What lesson, then, my brethren, did our Lord Jesus Christ wish to impress on His Church, when it pleased Him to have one castaway among the twelve, but this, that we should bear with the wicked, and refrain from dividing the Body of Christ? . . of one bread and both Peter and Judas partake, and yet what communion had the believer with the infidel? Peter's partaking was unto life, but that of Judas unto death. For that good 
bread was just like the sweet savior. For as sweet savior, so also does the good bread give life to the good, and bring death to the wicked. "For he that eateth unworthily, eateth and drinketh judgment to himself." "Judgment to himself," not to thee. 27

Thus, those who desired to remain in unity with charity partake well of the Body and Blood of Christ, but those who lack such unity have no such aid; on the contrary, they find it to be poison to the spirit. In emphasizing unity to the Donatists, Augustine often uses the figure of Bishop Cyprian who kept peace between Donatists and Catholics until the rebaptism controversy was brought to a council for final decision, comparing him to the Apostle Peter who once adhered to Jewish customs in his ministry, but who changed then upon exhortation by Paul for the sake of essential unity. ${ }^{28}$ However much was his interest in unity, he warned that the Church "does not abandon the unity of the good because of the wickedness of those whom she finds incorrigible." 29 Those who through hardness of heart reject the unity of the Church sin against the Holy Spirit and can never be forgiven -- and this includes any neutrals for "he does not gather with the Lord, scatters." 30 In commentary in Homily I on 1 John 1:1-11, Augustine finds that only His Church can be the instrument for the forgiveness of sins. Those who separate themselves from the Church and assert that Christ is only with their sect belie the presence of the Church in all nations and the sacrifice of Christ for the sins of the world. Augustine warns, ". . do not follow false justifiers who are in truth cutters off." He concludes that those who cut themselves off from the Church give scandal and commit grave sin, the greatest of which is a lack of charity:

- . But marvel not that it is unknown by these who hate the brethren, because they walk in darkness and know not whither 
they go, because the darkness hath blinded their eyes. They do not see the mountain: I would not have thee marve1; they have no eyes. How is it they have no eyes? Because the darkness hath blinded them. How do we prove this? Because they hate the brethren, in that, while they are offended at Africans, they separate thenselves from the whole earth: in that they do not tolerate for the peace of Christ those whom they defame, and do not tolerate for the sake of Donatus those whom they condemn.

The conclusion of Augustine was that unity was essential for the Church and that unity could be purchased only with a spirit of charity, even to the point of tolerance for those who seem to be following errant paths. Kung, on the other hand, sees the mark of unity to consist of a mixture of faith and love among the members of the Church resulting in a moral unanimity or sensus ecclesiae. ${ }^{31}$ What is of greatest importance, he feels, is that the church present itself credibly, so, in accordance with John $17: 21$, the world may believe. ${ }^{32}$ Yet this unity is spiritual in nature, rather than a uniformity so that various local churches, schools and theological systems may exist along with the universal Church which has one God, one Lord and one Spirit. 33 This position presents some problems in that most religious controversies center over difficult points while all sides praise unity. However, Kung finds that unity in Christ and reception of the sacraments will give effective world witness and bring about ecclesiastical unity through charity rather than the triumphalism which marks the schisms of the 11 th and 15 th centuries. ${ }^{34}$ Unlike Augustine, Kung feels that scriptural interpretation will develop to solve all controversies. Finally, he states that the multitude of churches must realize their common unity, and, by implication, that Catholics must surrender their claim as the exclusive Church of Christ and facile distinctions between membership in the true Church and the stigma of an erroneous conscience: 
- .. And if these churches baptize rapidly in his name -- which is not in dispute - - in which ecclesia are the baptized incorporated if not in his, the one ecclesia, of which body are they members if not the one body of Christ? And if these Churches also validly celebrate the Lord's Supper -- which is disputed in only a few cases (with justice?) what body do they receive and in what body are they united if not in his, the one body. . . . 35 Yet perhaps this lack of distinction is facile. If Church membership be required, which Kung accepts, then one who willingly accepted membership in a body which believed were not the Body of Christ, would find such membership inefficacious since he willfully separated himself from Christ. The Catholic Church denies the objective validity of the sacraments of certain other churches which are heretical in its view, and accepts the validity of the sacraments of schismatic churches. But in either case, its concern, as with Augustine, is with the state of the individual and his conscience. While grace flows through the sacraments, this does not prevent such grace from utilizing other channels of salvation. One thing can be certain -- the willful rejection of grace is the death of the spirit.

2. The Church is Holy. Augustine finds that the holiness of the Church is based on its law of love. Love comes from God, the dispenser of grace in the Sacraments administered in His name, rather than that of any man. Therefore, any man who cuts himself off from these signs of holiness cuts himself off from participation in the life of Christ. 36 Even martyrdom without love is a sacrifice in pride and iniquity (which he attributed, for example, to the Circumcilliones) and unable to aid the person who sheds blood. ${ }^{37}$ The presence of charity sanctifies the Church and gives it unity in a common Lord:

-... Let us then, my brethren, seek for those among the faithful who have something which bad men have not, and this will be "the wedding garment." If we speak of sacraments, ye see how 
these are common to the bad and good. Is it Baptism? Without Baptism it is true no one attaineth to God; but not every one that hath Baptism attaineth to Him. I cannot therefore understand Baptism, the Sacrament itself that is, to be "the wedding garment"; for this garment I see in the good, I see in the bad. Peradventure it is the altar, or that wich is received of the altar. But no; we see that many eat, and "eat and drink judgment unto themselves." What is it then? Is it fasting? The wicked fast also. Is it running together to the Church? The wicked run thither also. Lastly, is it miracles? Not only do the good and bad perform them, but sometimes the good perform them not. . . . In the church itself, hear the Apostle, "Are all prophets? Have all the gifts of healing? Do all speak with tongues?

What is that "wedding garment" then? This is the wedding garment: "Now the end of the commandment," says the Apostle, "is charity out of a pure heart, and of a good conscience and of faith unfeigned." This is the "wedding garment." Not charity of any kind whatever; for very often they who are partakers together of an evil conscience seem to love one another. 38

Those who lack such charity, according to Augustine, are like branches cut off from a vine, cut off from the life of the spirit. ${ }^{39}$ This holiness therefore is found only in the Church and cannot be found in those who wilfully exclude themselves from her. He concludes:

. If thou hold fast charity, neither in Christ shalt thou have occasion of falling, nor in the Church; neither Christ shalt thou forsake, nor the Church. 40

Kung, on the other hand, approaches the subject in a different light. Holiness, he finds, does not consist in the personal impeccability of the members thereof, but their response to the call of God through faith in the battleground on earth between the world and the Spirit. ${ }^{41}$ To make this response institutionally credible, the church must act in accordance with the will of God rather than for "petty interests" or "a pretended inspiration." 42 That will consists in constant reform and sanctification of the Church and its members. The members reform through penance, but the Church must keep itself credible (or worthy of belief in its witness) through adherence to the Word. ${ }^{43}$ Then alone is 
it Holy. The problem with this view is its necessity for the whole Church to be a witness to the Word, whereas previously, it was stated that the visible Church consists of sinners. Can there be a corporate withess without an individual witness?

3. The Church is Catholic. For Augustine, the catholicity or universality of the Church is to be understood primarily in a geographical sense, i.e. the Church is spread over the known world. This question received special attention in his controversies with the Donatists as he recounts in debate:

.. I thereupon asked him what was the Church within which it was the liberty of man so to live; whether it was that one which as Sacred Scripture had long foretold, was spread over the whole world, or that one which a small section of Africans, or a small part of Africa, contained. 44

The universality of the Church was the world-wide mission of that institution, rather than mere observation of precepts and reception of the sacraments without more, existing in one section of Africa as the Donatists claimed. ${ }^{45}$ In demonstrating the universality of the Church, Augustine twice uses the image of the gift of tongues whereby they had command of all languages (in contrast to the Donatist who spoke in Punic) for their mission. ${ }^{46}$ On another occasion, he used the symbol of the division of Christ's clothing in four pieces as symbolizing the spread of the Church through the four corners of the earth, and the gathering of the elect from the four corners on the last day, while the seamless garment itself represents the unity of the Church. ${ }^{47}$ While the Church began at Jerusalem, through zeal, blood and the Spirit, it has spread through al1 nations. ${ }^{48}$ He adds:

. . Let Stephan be killed, the Church of Jerusalem dispersed in confusion: out of it go forth burning brands, and spread 
themselves and spread the flame. For in the Church of Jerusa$1 \mathrm{em}$, as it were burning brands were set on fire by the Holy Spirit, when they had all one soul and one heart God-ward. When Stephan was stoned, that pile suffered persecution: the brands were dispersed, and the world set on fire. 49

This spread of the Word has been foretold in Scripture and, from Jerusalem outwards, is being carried in to all parts of the world. 50 It is this mission which constitutes the universality of the Church.

Kung finds the mark of catholicity to be based neither on geography, statistics, history or sociology, but on the patristic concept of "oecumene" or world-wide call to all Christians. 51 There can be an uncatholic local church, therefore, in those circumstances if by heresy or schism, it cuts itself off from the universal Church. However, Kung denies that this attribute applies solely to the Church of Rome:

How can we explain this exclusiveness, the way in which the attribute "catholic" has become associated with just this one "Catholic Church"? Is this not an indication that this Church has something others lack? Here, I do not mean its greater extent, its larger numbers, its wider variety, its more venerable age. Nor do I wish immediately to infer that the "Catholic Church" has a unique and exclusive quality by virture of which all other churches become uncatholic communities; what I have said about the one church and many churches still applies, and this kind of apologetical approach is no use to us here, , . .52

Kung describes the relationship between the Church of Rome and the other churches in historical terms as that of mother and daughter. The daughter "thinks there were very good reasons why she could no longer be living at home with mother." ${ }^{53}$ This type of analogy tends to justify schism as a natural product of historical development, which is compounded in the same passage by a statement that these "daughters" could not be expected to return to their mother's womb. Kung advocates joint exegetical and historico-critical studies of Scripture to sort out areas of agreement and disagreement on relationships among Christian bodies, 
but includes the primacy and infallibility of the Pope, the organization of the Church and the Marian Dogmas as problems of secondary importance, ${ }^{54}$ which some would question. Lastly, he finds that the universality of the Church is based on universal recognition of her truths, 55 although his later thoughts on linguistics may qualify that position.

3. The Church is Apostolic. Augustine apprehends this word in terms of a succession of Church leaders from Peter and the remainder of the Apostles. ${ }^{56}$ His works indicate that he regarded Peter as the Chief Apostle and that primacy is handed down to his Roman successors. 57 He also tends to view the legitimacy of the episcopal office (as the suc. cessor to the Apostolic ministry) upon its succession of office:

For if the lineal succession of bishops is to be taken into account, and hcw much more certainty and benefit to the Church do we reckon back till we reach Peter himse1f, to whom, as bearing in a figure the whole Church, the Lord said, "upon this rock, I will build my Church, and the gates of hell shall not prevail against it". . [Augustine here names the successors to Peter]. In this order of succession no Donatist bishop is found.

Now even although some traditor had in the course of these centuries, through inadvertence, obtained a place in that order of bishops, reaching from Peter himself to Anasthasius, who now occupies that see, --this fact would do no harm to the Church and to Christians having no share in the guilt of another. . . 58

Thus, the Petrine and Episcopal offices continued despite the moral state of their occupants. This succession of office was utilized by Augustine as the mark of the Apostolic Church, continuing in the place of the Apostles.

Kung broadens this concept considerably. He believes that the entire Church, especially in its functions of preaching the Word, is Apostolic. He is less concerned with discussion of lineage than the nature and continuation of the Apostolic ministry which is taken from 
the Hebrew, meaning "messenger of God." 59 . The Apostolic test of Kung consists of holding fast to the good news (I. Thess. 5:21) and struggling against any deviation therefrom, using Scripture as the norm. 60 Historically; he blames the adherence of bishops to worldly things to be the cause of their loss of credibility and the success of the Reformation. 61 To regain this credibility, Kung proposes a re-examination of the Apostolic character of the Church advocating its re-formulation in terms of service functions, without regard to hierarchy, which apostolic character remains unique and unimpeachable and succeeds, by its ministry, to the apostolic ministry. ${ }^{62}$ Further, he combines this approach with his theories of charisms and ministries described above, and his sense of the "priesthood of all believers" whereby every Christian partakes of ecclesiastical functions. The result is a succession of offices based on charism from the time of the Apostle until the present. ${ }^{63}$ Also, possibly unnecessary is the sign of ordination, the office based more on the Spirit than the formality of laying on of hands, though one must have faith to possess the office. ${ }^{64}$ The uncertainty of deciding whether one has sufficient faith to receive an office from the Church is somewhat problematical. In any case, in that the Church has ordered charisms and ministries in such a way that the pastoral ministry has many of the functions of the Apostolic office; nevertheless, each Christian has the duty of participation in the Church and spreading the Lord in the tradition of the Apostles.

The subjects have often found the marks of the Church to be interrelated. Augustine could hardly speak to the unity of the Church without mentioning its universality, nor can Kung speak to the Apostolic 
character of the Church without speaking of its sanctity in following the Word. The two agree essentially as to the nature of unity, holiness and universality of the Church, but differ to a great extent as to its Apostolic character. Augustine views the Petrine and Episcopal offices as the successors to the Apostolic ministry whereas Kung finds the Church itself as the successor, which body orders the charisms of those called to the pastoral ministry. The conclusions are not dissimilar as to effect, but differ as to emphasis. 
FOOTNOTES: CHA.PTER. III

1. De Baptismo, Book II. Structures, p. 390.

2. Ibid.

3. Ibid., Book III. The emphasis here is that Cyprian did not excommunicate those with whom he disagreed on matters of doctrine.

4. See for example Sermon 88 on John 10:17. In Ep. 87 to Emeritus, a Donatist, Augustine finds no proof from Scripture of their claim.

5. In Structures, Kung quotes Augustine as authority for the primacy of Scripture in a letter to the Emperor Maximinus:

I must not bring forward the Council of Nicea and you must not bring forward that Arminium (359), as if to prejudge the matter. For you are not subject to the first nor I to the second. Let matter dispute with matter, cause with cause and reason with reason. And let all be based on the authority of Scripture, not that peculiar to either one, but that common to both.

6. Infallible, pp. $39,48,50$. But see Justification, p. 108, in which Kung states that Scripture should be read only within the Church and, as such, in the light of its tradition.

7. Ibid.; p. 173. Structures, p. 344 .

8. Ibid., p. 352. Calvin believed councils were good for the Church in that:

1. The decision of the collected pastors carried great weight in the Church.

2. Assembly at one place made consensus easier.

3. Paul in I Cor. 14:29 prescribes it.

9. Kung asserts that infallibility (1) only explains, and does not add to Scripture; (2) has a generally human subject; (3) is not inspired, but mainly protected from error; (4) is merely a human utterance on the Word of God. Ibid., p. 361. Even if a council or the Pope should err in matters of faith, Kung believes that the Church is preserved in the truth, by its indefectable adherence.to truth.

10. Ep. 209.

11. Tractate 124 on John 21:19-25. See a1so Sermon 26 in Matt. 14:25. In Against Two Letters of the Pelagians, Ch. 5, Augustine accuses 
the Pelagians of circulating falsehoods to the effect that Pope Zosimus, and the "Catholic See," had approved their doctrines. In answering the statement, Augustine states:

- . But if, which would be far from the case, it had so been judged in the Roman Church concerning Caelestius or Pelagius, that those dogmas of theirs, which in themselves and in themselves Pope Innocent had condemned, should be pronounced worthy of approval and maintenance, the mark of prevarication would rather have to be branded on the Roman Clergy for this. . .

The same requirement of fidelity to Scripture, therefore, which binds Councils, also binds the Papacy.

12. Ep. 43. See also the discussion on Ep. 53 post.

13. Structures, p. 229. See also Infallible, p. 247; The Church, p. 451 .

14. The Cliurch, p. 477.

15. Structures, p. 245.

16. The Church, pp. 462-463.

17. Structures, pp. 229-237. The power of the office is derived from Scripture and its purpose is to strengthen the other Apostles and the Church.

18. Ibid., p. 242 .

19. Ibid.; p. 247.

20. Ibid., pp. 251-270. The question often arises as to conflicts of faith between the Pope and the Church. While judged by Scripture, Kung believes that a Pope even exroneously cannot excommunicate the remainder of the Church. At p. 314, he quotes Yves Congar to the effect that the Pope represents the entire Church by his office.

21. Ibid., pp. 271-281. However, Kung advises a middle road between "extreme": Papalism and "extreme" conciliaxism. P. 287.

22. Ibid., p. 293. Despite the many internal controversies of the early Church, Kung finds only the "spiritual" aspects of the Church, dealt with by the patristic and Medieval theologians, rather than the "legal" aspects (p. 290). However, his comments on patristic and medieval ecclesiology, especially councilar ecclesiology, setting forth the relationship of bishops, Pope and faithful within the Church are somewhat inconsistent.

23. De Baptismo, Book VI. 
24. A Treatise Concerning the Correction of the Donatists (Ep. 185).

25. Ep. 61, Augustine notes that the Donatists do many things in the same way as the Catholics, but their lack of charity makes them separate from the People of God. See also on the Creed, A Sermon to the Catechumens. In this work, Augustine stresses the holiness and Catholicity, as well as the unity of the Church.

26. Ep. 88; Enn. on Psalm 122; Sermon 21 on Matt. 12:32. Tractate 10 on John 2:12-21. The symbol of a vine, to represent Christ, and branches, to represent members of the Church, is also used by Augustine to demonstrate the need for unity. In On Catechising the Uninstructed, Ch. 24, he finds that this vine grows with the blood of martyrs, and is pruned to exclude the unfruitful, unfaithful branches. It follows then that the branch cut off from the vine cannot live. See also, On the Creed, A Sermon to the Catechumens.

27. Tractate 50 on John $11: 55-57 ; 11: 1-11$. See also Sermon 23 on Matt. 13:19.

28. De Baptismo, Books I, II, III, and VI. See a1so Enn. on Psalm 120.

29. Ep. 93. Further, Augustine adds that the spirit, which dwe11s in the Church is undivided. Sermon 21 on Matt. 12:32.

30. Sermon 21 on Matt. $12: 32$.

31. Structures, pp. 30, 35. Kung feels that the characteristics of the Church do not lend themselves to an apologetic approach. The Church, pp. $266 \mathrm{ff}$.

32. Structures, p. 29 .

33. The Church, pp, 273-274. Kung, as Augustine, points out the necessity of unity using Scripture as authority, i.e. I Cor, 10-20, Gal . $3: 27 \mathrm{ff}$, Rom. $12: 3-8$, Acts $2: 42$ and $4: 32$, John $10: 16$ and $17: 20-26$, Eph. $4: 10$. Ibid., p. 272 .

34. Ibid., pp. 282-296.

35. Ibid., p. 285 .

36. Homily I on 1 John $1: 1,2: 1$. Tractate 27 on John $6: 60-72$.

37. Sermon 88 on John 10:14.

38. Sermon 40 on Matt. $12: 2$.

39. Tractate 27 on John 6:60-72, Sermon 21 on Matt. 12:32.

40. Homily I on 1 John $12: 1$. As noted above, the parable of the sower ("He that gathereth not with Him scattereth abroad") in, for example, Sermon 21 on Matt. $12: 32$ and the parable of the wheat and tares in, for example, Tractate 6 on John 1: 32, 33 are examples 
of those in the same circumstances who are separated for lack of charity.

41. The Church, pp. 322-326. As authority, Kung cites Rom. 15:25, I

Cor. 16:1 and 15; II Cor. 8:4; I Peter $2: 19$; Eph. 2:21. This battle will be won on the last day (Eph. 5:27). He quotes Augustine, Retractions II, 18, with approval:

Whenever in my books I have described the Church as being without spot or wrinkle, I have not meant to imply that it was already so, but that it should prepare itself to be so, at the time it too will appear in its glory. In the present time, because of the inexperience and weakness of its members, it must pray every day anew: Forgive us our trespasses. . .

42. Structures, pp. 57-59. This same norm must be predicted of the teaching authority, whether of the bishops or the Papacy.

43. The Church, pp. 332-345. Kung substantially agrees with Augustine that the Church is a communion of saints and sinners, rather than a body of the pure, finding the source of its holiness in Christ. Justification. p. 234.

44. Ep. 44.

45. Ep. 93. Augustine also chided the Donatists for their African orientation in Homily 2 on I John 2:12-17 and Sermon 88 on John $10: 14$.

46. Tractate 6 on John 1:32, 33. Sermon 21 on Matt. 12:32.

47. Tractate 118 on John $19: 23,24$.

48. Homily 1 on I John $1: 1$-II:1, Homily II on 1 John II $12: 17$. Sermon 66 on Luke $24: 36$. The Church includes all the just, including the ange1s, in one bond of equality. Tractate 107 on John 17:9-13. See also on the Profit of Believing.

49. Sermon 66 on Luke $24: 36$.

50. See Ep. 53, which states, in part, "We rely, however, not so much on these documents [in the Donatist controversy] as on the Holy Scriptures, wherein a dominion extending to the ends of the earth among all nations is promised as the heritage of Christ. . . ."

51. The Church, p. 303. See also the two quotations from Augustine on p. 306. On this basis, Kung finds the medieval councils were not ecumenical. Structures, p. 47.

52. Ibid., p. 307.

53. Ibid., pp. 317-318. 
54. Ibid., p. 311 .

55. Structures, pp. $45-46$.

56. Sermon 26 on Matt. 14:25. See a1so On the Profit of Beleiving.

57. Ibid.; Ep. 43; Ep. 209.

58. Ep. 53 .

59. The Church, p. 350. Kung finds the word "Apostle" used once each in Matthew, Mark and John. Luke uses the word six times in his gospel and 28 times in Acts. Paul uses it 29 times (five times in the Pastoral Epistles). It usually means bearer of news, but also refers to the twelve, ambassadors of a local church, missionaries and Christ. The number 12 is significant in that it represented the twelve tribes of the New Israel and usually includes the original eleven and Paul. Pp. 346-351.

60. This is also the test of Augustine, Luther and Calvin. Structures, pp. $107-117$.

61. Ibid., p. 134 .

62. The Church, pp. 354-359.

63. Structures, pp. 180-181.

64. Ibid., pp. 184-189. Kung sees three ways of passing on the ministry: by commission from other office holders, by commission by the Church, and spontaneously from one's charism. 


\section{CONCLUSION}

The ecclesiological views of the two writers under consideration are molded to a great degree by the circumstances in which they operated. Thus, Kung spends little time on the necessity of a pure administrator of the sacraments as a prerequisite to their validity and Augustine spends little time on the Papacy. Where their great minds have not fixed their gaze, it is almost futile to speculate as to their conclusions.

Yet from the positions which the times required them to take, there exists sufficient material to deduce some general conclusions and from these conclusions an ediface can be erected, formed by the patterns of thought which have been made known to us.

At the apex of the structure, and forming the point to which the whole Church is directed, is Christ, the God-man, who cal1s all humanity to follow him. It is He who is the foundation and the cement which holds the bricks together. For both, the individual must first acknowledge this foundation of belief and accept the Eschatology which proceeds from that belief. In accepting Christ as the norm for his actions, the Christian must then attempt to conform his actions to these standards and must do so in communion with his fellow believers in Christ.

It is here that the two diverge. Augustine battled the Donatist schism and preached the unity of the universal church against the factionalism of his enemies. Kung is unwilling to exclude any believer in Christ from the Church, preferring to drop the distinction between Catholics and others suffering from "invincible ignorance." While 
Augustine admits there may be those saved who are not inside the Church, he requires absolute ignorance (still finding some sin even in this) and finds it almost impossible to believe that one outside the Catholic Church does not do so out of sheer malice.

While both acknowledge Christ as the source of Church unity, there are other diversions regarding authority which separate the two. Augustine looks to Scripture as the norm for church life; indeed, his writings are replete with scriptural citations as authority for his positions. He studied and had a working knowledge of the Scripture and was able to refer to various parts of the Bible to supplement his position with regard to a questioned interpretation. It may fairly be said, however, that with all his skill and diligence, Augustine lacked many of the critical tools available for present-day exegesis and may have found more difficulty in the use of Scripture as authority in certain areas, though he acknowledged development of understarding of the Word in time. Hans Kung has these tools available and presents many problems, especially justification, in all their Scriptural complexity. However, his skill in theology has forced him away from his original trust in Scripture as the norm for life. He finds Scripture, as well as the teaching authority of the Church, to be enmeshed in the problems of linguistics. He concludes that neither the Protestant belief in the Bible nor the Catholic reliance on the teaching authority of the Magisterium are of comfort to man -- al1 he can take comfort in is the feeling that God is with us and the Kerygma (good news) has been given us.

Insofar as structure is concerned, Augustine spends little time in this area. He acknowledges episcopal jurisdiction over selected areas 
and a primary of the See of Rome. Kung, in an attempt to free the Church from "legalism" becomes enmeshed in it himself as he examines the claims of the Church and Papacy and compares them to Scripture. While expressing some concern over the origin of the episcopacy, he apparently accepts the same, but finds more difficulty with the Papacy, which he accepts as the fulfillment of a ministry of service to the Church. However, he emphasizes that the basic unit, after the local church, is the episcopacy.

The two structures, placed side by side, do not fundamentally differ in their bases nor their objectives. It is in building the wa1ls that they differ to some extent. Augustine demanded unity, but required charity first. He was willing to remain in communion even with the Donatists whom he thought so clearly wrong according to Scripture, if they would share a devotion to God and return the demonstration of love from other churches. Kung would accept all who believed in Christ on the same basis. Augustine appealed to Scripture; Kung to the Holy Spirit. Augustine does not require a rigid ecclesiastical structure; neither would Kung.

The world-views of the two, however, reflect their differences. Augustine did not desire to be bishop, but was taken from his monastic 1ife by the demands of the African Church. His ideal is the monastic community, wherein the inhabitants work, pray and study Scripture together. Kung is less prone to withdraw from the world. A cleric himself, his works encourage involvement of the Christian with the world. to change it. Augustine felt that the world should be ministered to, but he also felt an antagonism between Saeculum and spirit, an antagonism which could never be reconciled. His trust in man, at its peak in his 
Platonic-Christian period immediately following his conversion, became nearly nonexistent during his anti-Pelagian campaigns. As he grew older, Augustine was more inclined to attribute wilful evil to those with whom he engaged in conflict. The issues at that time seem much more clear to him than to Kung in this century.

With this difference in emphasis comes a difference in structural elements in their respective ecclesiologies. For Augustine, the bishop is the bulwark of faith in his diocese, keeping his flock, refuting heretics and schismatics, ministering to the ills of the flesh and spirit, and standing as a beacon of leadership. Kung views the role of the bishop in somewhat less active terms -- his role is one of service to his flock, one which leaves the work of theology to the theologians, a presiding officer serving the local church. Similarly, the Church differs as the view of man differs. The Church had, for Augustine, positive and negative roles. Positively, it prepared men for salvation. Negatively, it kept them away from intellectual and worldly temptations. For Kung, the entire emphasis is positive. Viewed against the broader background of the contemporary Church, the emphasis is a steady trend towards the position of Kung, in the deletion of the meatless Friday requirement, the abolition. of the Index of Books and the clamor for optional celibacy. The trend towards Christian responsibility, however, must stress the altemative of failure to follow a given good, and further, the problem of what a Christian should do to be his brother's keeper remains troublesome. It can well be concluded that the effects of an Augustinian view will remain of some concern to the Church.

Another less emphasized, but important distinction between the two lies in the concept of each of the mutability of the Church. Augustine 
leaves, in his writings, an impression of the church being more intimately involved in a divine plan for salvation than kung would allow. The corporate being of the Church, apart from her membership, occupies a favored status. Kung finds that he cannot find such a separate corporate entity and involves himself with the human problems of the Mystical Body apart from divine considerations, such as infallibility and the impossibility of adequate verbal propositions. Augustine finds that the promises given the Church have been and continue to remain capable of fulfillment, a belief in divine control underlined by his later positions of Predestination. The Church, like Scripture or truth itself, retains an unchanging essence, though its qualities or aspects may be viewed in the varying light of changing circumstances. For Kung, the purpose of the Church remains the same but is different in history to individual believers as the Kingdom moves to manifestation.

Another aspect of interest is the view of the Church as an organization, a characteristic stressed by Augustine, and of the stress placed by Kung on individual choice for a response to the call of Christ to join the community of the elect. Once the choice is made and adhered to, there is no means by which the choice can be defeated. Admittedly, however, adherence is a product of grace and not a product of choice in the Pelagian tradition. Augustine finds such a grace, though dispensed through the instrumentality of the Church, not necessarily as a product of membership, but as a part of the unknown Will of God. On the opposite side of each coin, Augustine intimates strongly that the lack of Church membership would make salvation impossible, whereas Kung does not seem to regard Church membership as necessary for life or salvation. For Kung, one can be a member of the Church on his own terms with God, and 
perhaps occasional community participation. Further, among denominations, a11 who answer the Call of Christ, this being the essence of membership, are members of the Church, whereas for Augustine, it is the form of the response which is as important as the response itself -- such form being in obedience to the duly constituted authorities of the Body of Christ. The views taken by the writers are as similar in some areas as they differ in others. The controversy over the nature of the Church will continue, probably indefinitely, without precise answers coming forth. Yet in two men of dissimilar backgrounds and circumstances, there has been some clarification of some of the problems which must be considered in commencing fresh inquiries. 


\section{A SELECTED BIBLIOGRAPHY}

Brown, Peter, Augustine of Hippo. Berkeley (Univ. of California Press, 1967)

Colish, Marcia. The Mirror of Language. New Haven CYale Univ. Press, 1968) .

Kung, Hans. Justification. London (Burne and Oates, 1964).

Kung, Hans. Structures of the Church. New York (Thos. Nelson and Sons, 1964).

Kung, Hans. The Church. New York (Sheed and Ward, 1967).

Kung, Hans. Infallible? An Inquiry. (Doubleday and Co., Inc., 1971).

Ladner, Gerhart. The Idea of Reform. New York (Harper and Row, 1967).

Schaff, Philip. The Nicene and Post-Nicene Fathers. Ann Arbor (CushingMallory, 1946). Especially the following:

A Treatise Concerning Correction of the Donatists

Expositions on the Book of Psalms

Faith of Things Not Seen

Homilies on the Epistles of John

Homilies on the Gospels of John

Letters $93,103,111,126,133,137$

On Baptism, Against the Donatists

On Christian Doctrine

On Holy Virginity

On the Creed, A Sermon to the Catechumens

On True Religion 
Sermons $1,12,21,26,43,44,66,79,80,88$

The City of God

The Letters Against Petilian 